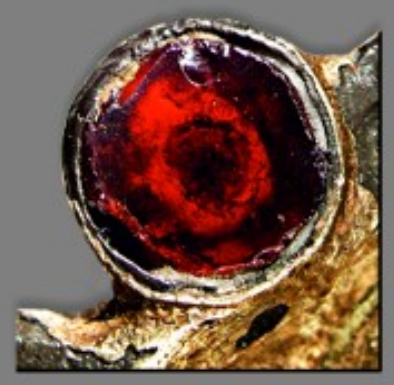

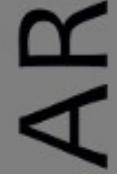

$\sim$

ш
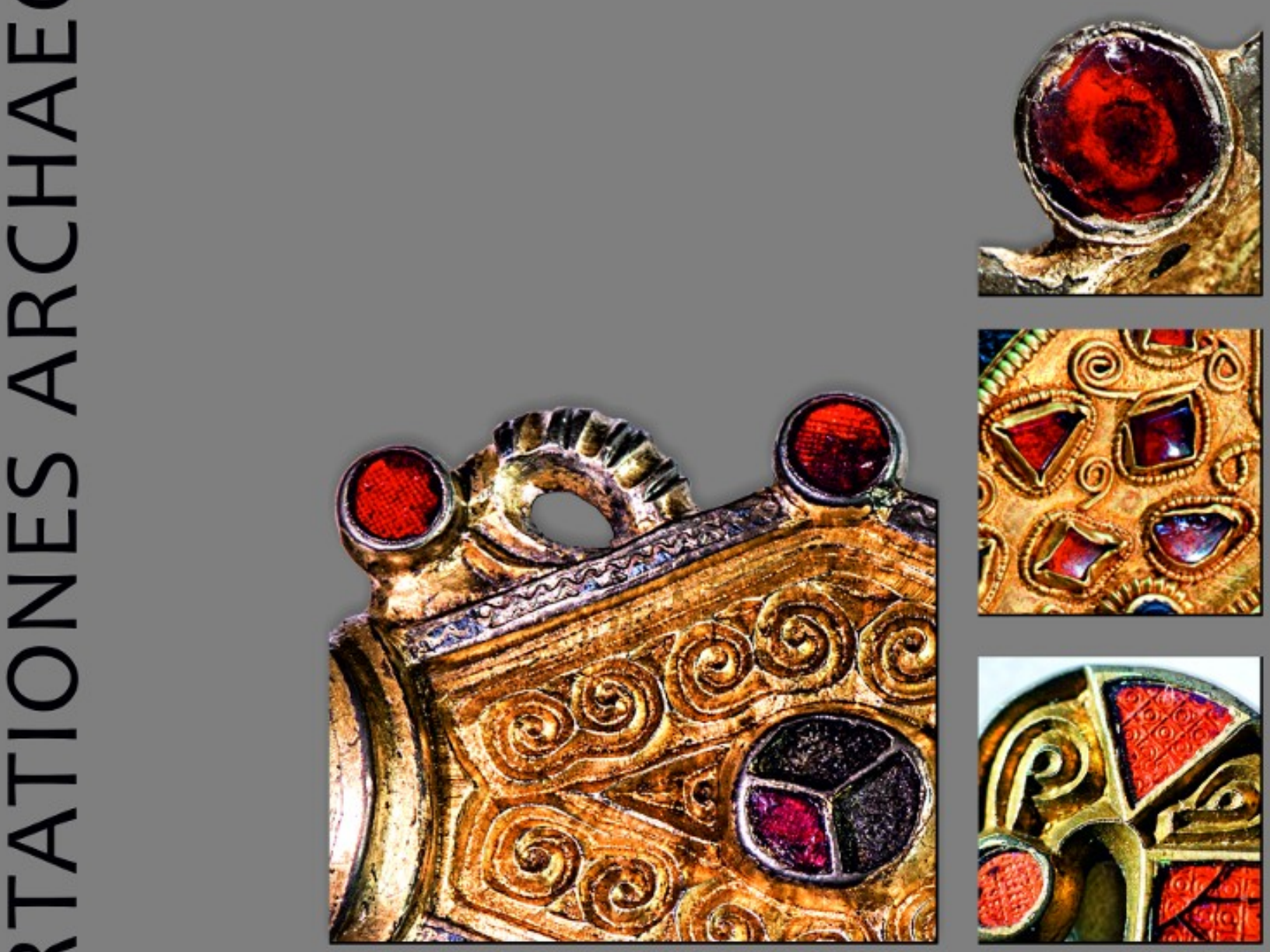

E

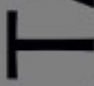

œ

山

n

ก

$\overline{0}$
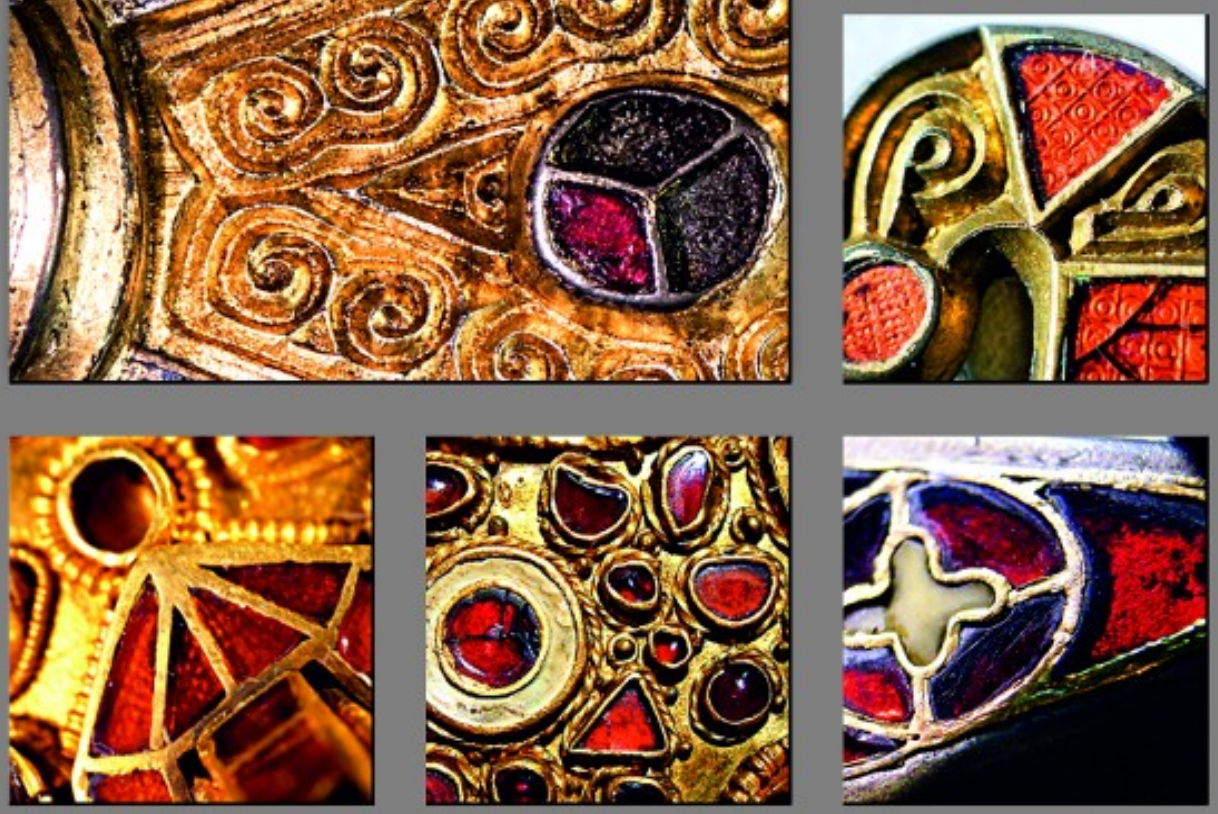

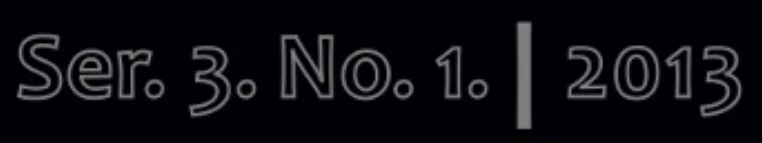




\section{Dissertationes Archaeologicae ex Instituto Archaeologico}

Universitatis de Rolando Eötvös nominatae Ser. 3. No. 1.

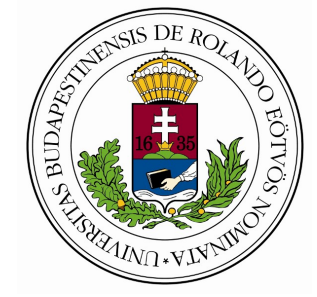

Budapest 2013 
Dissertationes Archaeologicae ex Instituto Archaeologico

Universitatis de Rolando Eötvös nominatae

Ser. 3. No. 1.

Editor-in-chief:

DÁvid BARTUS

Editorial board:

LÁSZLÓ BARTOSIEWICZ

LÁSZLÓ BORHY

ISTVÁN FELD

GÁBOR KALLA

PÁL RACZKY

Miklós SzABÓ

TIVADAR VIDA

Technical editors:

DÁvid BARTuS

GÁBOR VÁCZI

ANDRÁs BöDŐcs

Proofreading:

Zsófia KondÉ

SzILvia SzÖLlősI

Available online at http://dissarch.elte.hu

Contact: dissarch@btk.elte.hu

\section{$\underline{\text { PKP }}$ \\ PUBLIC \\ KNOWLEDGE \\ PROJECT}

(C) Eötvös Loránd University, Institute of Archaeological Sciences

Budapest 2013 


\section{Contents}

\section{Articles}

Melinda TORBÁGYI - István VIDA

The coin hoard of Abasár

Anikó BózsA

21

Roman mirrors from a private collection in the Hungarian National Museum

Lajos JuHÁsz

45

The Biesheim cameo - a reinterpretation

\section{Methods}

Péter CsIPpÁN

$A z$ állatcsont, mint információhordozó leletanyag

Kata DÉvAI

Terminológiai alapfogalmak régészeti korú üvegtárgyak elemzéséhez

Lőrinc TimáR - Zoltán Czajlik - Sándor Puszta - Balázs Holl

$3 D$ reconstructions using GPR data at the Mont Beuvray

\section{FIELD REPORTS}

Zsolt MESTER

Excavation at a new Upper Palaeolithic site of the Eger region (Northern Hungary)

László BORHY - Dávid BARTus - Emese SzÁmadó

Short report on the excavations at Brigetio (Szőny-Vásártér) in 2013

Dénes HulLÁm - Zsófia RÁcz

Report on the participation of the Eötvös Loránd University at the Wielbark Archaeological Field School in Malbork-Wielbark, Poland

Gábor VÁczi - Dávid BARTus

Short report on the excavations at the site Makó - Igási Ugar

Maxim MoRdovin

Short report on the excavations in 2013 of the Department of Hungarian Medieval and Early Modern Archaeology (Eötvös Loránd University, Budapest)

\section{THESIS ABSTRACTS}

Kitti KÖHLER

Biological reconstruction of the Late Neolithic Lengyel Culture 
Cultural connections and interactions of Eastern Transdanubia during the Urnfield period

Orsolya LÁNG

Urban problems in the civil town of Aquincum: the so-called „northern band”

Nikoletta SEY

Questions of bronze workshops in Roman Pannonia

Kata DÉvaI

Glass vessels from Late Roman times found in graves in the Hungarian part of Pannonia

Eszter HORvÁTH

Gemstone and glass inlaid fine metalwork from the Carpathian Basin:

the Hunnic and Early Merovingian Periods

Gergely SzEnTHE

Vegetal ornaments in the Late Avar decorative art

Péter LANGó

Relations between the Carpathian Basin and South East Europe during the 10th century.

The evidence of the minor objects

Ciprián HoRvÁTH

The Cemeteries and Grave Finds of Györ and Moson Counties from the Time

of the Hungarian Conquest and the Early Árpádian Age

András Sófalvi

The border- and self-defence of Szeklers from the Medieval Age till the Age of Principality.

Castles and other defence objects in the settlement history of Udvarhelyszék 


\title{
Short report on the excavations in 2013 of the Department of Hungarian Medieval and Early Modern Archaeology (Eötvös Loránd University, Budapest)
}

\author{
MAXIM MORDOVIN \\ Institute of Archaeological Sciences \\ Eötvös Loránd University \\ amalrich@gmail.com
}

\begin{abstract}
The Department of Hungarian Medieval and Early Modern Archaeology carried out or participated at excavations on eight sites cooperating with several foreign institutions in 2013 (Fig. 1). These sites are Tusa - La Şanţuri (Romania), Văcăreşti - Sándor manor house (Romania), Filakovo - Dolný hrad (Slovakia), Zvolen, Pustý hrad Dolný hrad (Slovakia), Čabrad' Castle (Slovakia), Bánd - Essegvár (Hungary), Visonta (Hungary) and Drégely Castle (Hungary).
\end{abstract}

\section{Tusa - La Şanțuri (Romania) \\ April-May 2013}

With the County Museum of History and Art, Zalău (Zsolt Csók - Maxim Mordovin). ${ }^{1}$

The castle of Tusa is situated on a relatively small hill $(489 \mathrm{~m})$ with steep slopes, $3 \mathrm{~km}$ south west of the present day Tusa village, just above the confluence of Berettyó (Barcău) and Tapolca rivers. The site is very complex; its core consisted of a small plateau encircled by multiple lines of fortifications (Fig. 2). The whole fortified territory is cca. 3 ha, however, the core of the castle is not larger than several hundred square metres. There are no known written sources concerning this castle, we do not even know its original name. The present day toponym - La Şanţuri - means simply "The Earthworks". The closest village, Tusa (Hungarian: Tuszatelke) is first mentioned in 1341 and by that time already belonged to the castle of Valkó.

The only previous archaeological research at the site carried out in 1994 and led by Horea Pop and Ioan Bejinariu (County Museum of History and Art, Zalău) revealed a single shred of undefinable prehistoric pottery. At the same time a larger amount of 11th-12th century pottery was collected on the surface.

This year we continued the excavations of 1996 prolonging that trench (S1) through the third and fourth lines of defence (S2 and S3) and making a new one in the same direction across the south-western (outer) bailey (S4). We expected relatively thin layers and moderate amount of finds. Fortunately the results exceeded all our expectations.

1 The site director was Zsolt Csók with Maxim Mordovin's assistance. Participants were: Mária Vargha (Central European University), Bogáta Bárdi, Dóra Hegyi, Bianka Kovács, Anna Mikesy, Zsófia Nádai, Emese Szalai, Villő SzekeresUgron (Eötvös Loránd University). 
According to the preliminary evaluation of the observed stratigraphy of the site and the finds, the fortification had at least two major medieval phases. The first medieval settlement was established at the hill not later than the first half or middle of the 13th century on the place of an earlier, prehistoric site. There are no data whether the latter was fortified. There are neither any known traces of any defensive structures of the earliest medieval site. We can only assume based on the contemporary parallels that sites situated on tops of the hills in most cases must have had at least some kind of ramparts.

The first medieval phase ended yet in the middle or the second half of the 13th century. We found unambiguous traces of a huge fire in all three trenches. There were some not too characteristic fragments of pottery datable to the 13th century and a lot of iron nails on the burnt surface of this phase. There is an intriguing possibility to narrow this dating and to connect the destruction of the castle to a significant historical event known from the written sources. The Tartars invading Hungary, after the siege of the castle of Cluj-Mănăştur (Kolozsmonostor) split in two and continued their way through the Meszes- and Királypaths. Both of these routes lie quite close to Tusa thus the investigated castle might have been besieged and destroyed during this invasion.

Anyway, after the fire the whole site was completely changed and the castle gained its present day plan. The central part of the fortification was restricted to the very centre of the upper plateau; two small outer baileys were created south-southwest and north of the core divided from it by enormous ditches, and four more defensive lines were constructed around them. Each of these defence-structures consisted of a wide and deep ditch cut directly into the rock (Fig. 3), and of dry stone walls made of the rocks quarried from the ditches (Fig. 4). The ditches cut the earlier destruction layers and the foundation of the stone ramparts was laid just on the earlier surface. This phase was very rich in different finds, e.g. pottery, arrowheads, spurs, etc. All of them can be dated to the second half of the 13th-first half of the 14 th century.

There are still many yet unanswered questions concerning the site. We do not know the precise function of the two phases. There is no explanation for the appearance of 11th-12th century pottery on the site. There is neither any acceptable answer where and why the site was abandoned.

\section{Văcăreşti - Sándor manor house (Romania)}

\section{July 2013}

\section{With the Harghita County Museum, Miercurea Ciuc (István Botár - Maxim Mordovin). ${ }^{2}$}

The remains of a manor house situated on a hill above Văcăreşti village (Hungarian: Vacsárcsi) are traditionally associated with the Sándor family from the neighbouring village Csíkszentmihály. The written sources mention the village only from the 16th century but there is no undoubted, authentic document concerning the manor house.

This year we continued the research project started in 2012 focusing on the main survived part of the building complex of the manor. That is a huge stone cellar originally vaulted, ori-

\footnotetext{
2 The site directors were István Botár and Maxim Mordovin. Participants were: Bogáta Bárdi, Márk Domokos, András Fazekas, Dorottya Györkös, Dóra Hegyi, Anna Herbst, Andrea Kocsis, Tünde Komori, Bianka Kovács, Zsófia Nádai, Teodóra Polyák, Emese Szalai, Gábor Szmok, Ágoston Takács (Eötvös Loránd University).
} 
ented east-west. It had timber pavement supported by wide foundation pads. In 2013 we excavated the western entrance of the cellar with some traces of the steps (Fig. 5-8). The most important find in this year was a coin found on the surface preceded the construction of the building. The construction layer of the survived cellar covered the layer where the coin was found. The coin was issued in 1596 by Rudolf II, King of Hungary and Holy Roman Emperor and thus this part of the manor house cannot be dated earlier than the 17th century.

There is no unambiguous evidence whether there was a stone building above the cellar; moreover, the relatively thin layer of stone debris suggests that the upper part had timberframed structure. The large amount of iron nails found all around the building supports this idea. At the same time, smaller nails indicate the character of the roof tiles as shingles. In one of the trenches we found some traces of a timber-framed structure attached south to the building. Its grade beams were laid on large pad-stones (Fig. 10).

Beneath the early modern layers late medieval deposits were observed with significant amount of pottery and some iron objects (buckles and knives). In 2012 we could identify an earlier, timber framed manor house datable most probably to the 15th century, destroyed by fire, but this year we have found no clear traces of any other medieval buildings.

Maybe the most interesting finds from the earlier medieval period (11th-12th centuries) were some rocks protruded from the subsoil, with very clear incised traces of medieval ploughing on their surface (Fig. 9). This clearly shows that already in such an early period of the Kingdom of Hungary this territory was not only inhabited but even the higher terraces of the Ciuc-Basin were already arable.

\section{Fil'akovo - Dolný hrad and Zvolen, Pustý hrad - Dolný hrad (Slovakia)}

\section{July-August 2013}

With the Constantine the Philosopher University, Nitra and the Institute of Archaeology of the Slovak Academy of Sciences, Nitra (Noémi Pažinová - Ján Beljak). ${ }^{3}$

The excavations of Filakovo - Lower Castle (Dolný hrad), Zvolen, Deserted Castle - Lower Castle (Pustý hrad - Dolný hrad) and Pet'uša Castle are part of the International Field School of Archaeology (http://www.karch.ff.ukf.sk/summerschool/) organised by the Constantine the Philosopher University, Nitra and the Institute of Archaeology of the Slovak Academy of Sciences. The whole project was sponsored by the Visegrád Fund. The Eötvös Loránd University has participated in this for the last several years. This year we joined the excavations of two sites, namely at Filakovo and Zvolen.

The castle in Filakovo is originated in the first half of the 13th century and already men tioned in a letter addressed to the pope in 1241 as one among several fortifications not occupied by the invading Tartars (Fig. 11). The significance of the castle remained throughout the whole Middle Ages and rouse quite high again in the 16th-17th centuries, when it became a border castle during the Ottoman Wars. The castle of Filakovo was in the Ottoman hands from 1554 until 1593. In this period it was besieged several times, which led first to lesser but from the 17th century to larger alteration, changing the medieval appearance of the for tification completely. The largest structure from the 17th century is the so-called Lower Cas-

3 Participants were: Márk Domokos, Dóra Hegyi, Réka Juhász, Enikő Kovács, Anna Mikesy, Zsófia Nádai, Ágnes Szabados, Tamás Szolnoki, Dávid Szvorák, Balázs Tóth, Nóra Ujhelyi (Eötvös Loránd University). 
tle made originally as a timber-earth fortification (Hungarian: palánk; Fig. 12), and subsequently, but yet in the 17th century being reinforced by huge stone walls and bastions.

This year under the direction of Robert Malček and Viktória Titton we participated in the archaeological excavation of the above mentioned timber-earth lower fortification of the castle. The traces of the fortification appeared mostly in the form of a very complex net of postholes (Fig. 13-14). The filling of the palisade contained mainly late 16th century finds, namely stove tiles, glazed pottery, iron nails and lead bullets. A fragment of a 16th century china cup is also worth to be mentioned (Fig. 15).

In Zvolen we continued the long lasting archaeological project of excavation and reconstruction of the Deserted Castle - Lower Castle under the direction of Noémi Pažinová and Ján Beljak. The 12th-13th century castle was hardly occupied during its relatively short existence. It consisted of an enormously huge keep (Fig 16) in the south-eastern "corner" of the castle, long stone curtain walls built on the perimeter of the mount, a double gate (probably a gatehouse) on the western and a postern gate on the northern side of the curtain wall.

In 2013 the Hungarian team of archaeology students led by Maxim Mordovin investigated the inner side of the western (main) gate of the castle (Fig 19). Remains of two ovens were excavated close to the gate (one of them was already found some years earlier). The medieval deposits connected to the ovens contained only 13th century finds, predominantly pottery and several dozen nails. However, two significant small bronzes were also found here: a little bronze buckle (Fig. 17) and an embossed copper alloy plaque depicting a dragon (Fig. 18). ${ }^{4}$

\section{Čabrad' Castle (Slovakia)}

\section{July 2013}

With the Institute of Archaeology of the Slovak Academy of Sciences (Fán Beljak - Mordovin Maxim). ${ }^{5}$

The castle of Čabrad' nowadays is located in a relatively remote area, in the forests of Krupina, cca. 5-6 km from the closest village Čabradský Vrbovok, on a steep rocky mount, in a bend of Litava River. Being among the largest castles of Slovakia its history goes back to the 14th century. The earliest data regarding this stronghold are a bit confusing since there were two castles with the same name not too far from each other, most probably until the middle of the 14th century. Since none of them was ever excavated now it seems that the smaller one located approximately $4 \mathrm{~km}$ east of Čabrad' on the hill called Pustý hrad (Deserted castle) might have been the earlier one. The present day Čabrad', however, might have been built only in the 14th century. Anyway, since the last one is not only among the largests but at the same time is one of those which were inhabited for the longest period, all visible remains cannot be dated prior to the 16th-17th centuries (Fig. 20). The local legend says that the castle was set on fire by its owner, count Fransiscus, the last male member of

4 Beljak, J. - Pažinová, N. - Šımкovic, M. 2013: Zvolenský Pustý hrad - Dolný hrad 2013: VS 59/2013. Výskum na vedecké a dokumentačné účely. Nitra, AÚ SAV.

5 Participants were: Dóra Hegyi, Réka Juhász, Andrea Kocsis, Tünde Komori, Enikő Kovács, Sára Lantos, Ágnes Szabados, Villő Szekeres-Ugron, Tamás Szolnoki, Balázs Tóth, Nóra Ujhelyi (Eötvös Loránd University). 
the Koháry family in 1812 . The family had already moved by this time to the nearby, more comfortable and modern château Antol.

There used to be a village beneath the castle, which was abandoned in 1960s and which has almost completely disappeared since then. Only an empty church founded in 1813 just after the fire and some houses remind the former community.

The castle of Čabrad' has very complex layout. Since no proper building historical research was ever done here, there is no possibility to distinguish or to date any building phases. In its present state the castle can be divided into four parts. The core is located on the highest spot of the rock and consisted of a huge tower with slight remains of a chapel and of the upper ward. The second and the third parts are attached consequently north of the first one but situated a bit lower. The second was arranged around the second-middle ward and had two palace wings, the older on the western and the younger on the eastern side of the ward. Some buildings of most probably economic character were situated on the northern side of the yard separating it from the third part of the castle. There was a separate gatehouse, which connected the third and the second parts. The third courtyard had buildings only on its northern part and was connected to the third gate tower on the eastern side (Fig. 21). This one was the largest such tower in the castle, having at least three storeys and two huge dou ble gates - one on the southern and another on the western sides. The fourth part is the socalled lower castle actually consisted of the outer bailey encircled by the outer curtain walls and fortified by an enormous gate tower. That one has two parts, the reconstructed smaller gatehouse originated probably from the 16th century and later in the 17th century was reinforced and enlarged by a triangular bastion. Originally the first and the third gates were accessible only via drawbridges led above deep ditch cut into the rock.

The condition of the ruins became critical by the late 1980s after the collapse of the northern half of the central tower. In the late 1990s a civil initiative brought to life a non-profit association called RONDEL led by Albert Loydl with its main aim to save the remains conserving the wall stubs, stabilising the surviving vaults, etc.

In 2013 the restoration works faced the need of archaeological research at some places of the castle, namely in the second and around the third gate towers. The archaeological excavation was coordinated by Ján Beljak (Institute of Archaeology of the Slovak Academy of Sciences, Nitra) and led by Maxim Mordovin with Albert Loydl's assistance.

In the southern expansion of the second gate six small square pits were made for the posts supported the new protecting roof. These pits reached only some highly disturbed 19th early 20th century debris layers with significant amount of finds.

At the same time three larger trenches were opened inside and in front of the southern façade of the third gate tower. Inside Trench 3 we observed and documented the collapsed vaults of the upper storeys of the building and the filling layers of the vaulting containing late medieval and 16th-17th century material and we cleaned out an embrasure in the eastern wall (Fig. 22). In the second trench we stopped as we reached the fallen remains of the carved elements of the eastern side of the southern gateway, leaving it in situ (Fig. 23) enabling a proper reconstruction. In the first trench we removed the debris of the tower and reached the surface of the drawbridge-pit. This pit was cut into the rock and closed by perpendicular stone walls on its northern and southern sides. The whole structure was com- 
pletely filled up in the second half of the 18th century, around 1762-1763 according to the coins found in it (Fig. 25). The two weeks of excavation were only enough to get to 3 metres depth from the initial surface (cca. 3-4 metres more left there). The filling was composed of many thin layers (Fig. 24) with enormous amount of finds. All these finds and their quantity refer on one hand to a very intensive life went on in the castle in that period, and on the other hand to great renovation works took place there. The number of the late renaissance and early baroque stove tiles (Fig. 26-28) - we have found fragments of almost one hundred pieces - shows that most of the 17th century and some 18 th century stoves were replaced in the second half of the 18th century. Also, there were thousands of sherds of different types of ceramics including fine and luxury wares. Many objects of the late 18th century tableware were also found, e.g. forks, knives, glasses, etc. (Fig. 29-30).

The short and limited excavation could not answer any of the questions concerning the building history of the castle. However, it produced a great amount of significant objects spectacularly representing an 18th century aristocratic household.

\section{Bánd - Essegvár (Hungary)}

\section{July 2013}

Eötvös Loránd University (István Feld, Dóra Hegyi, Szabolcs Balázs Nagy).

The village of Bánd lies $10 \mathrm{~km}$ west of Veszprém. There is a little but steep slope above the village, where the castle of Esseg (Hungarian: Essegvár, Fig. 31) can be found. Now only the remains of a 9-10 m high tower are visible on the east side of the slope. Besides that only the curtain walls of the castle can be followed on the surface.

The stronghold was built in the second half of the 13th century but first mentioned only in 1309. It served as an average noble residence throughout the Middle Ages. It disappears from the written sources after the Ottoman conquest of Hungary, so it is likely that after the fall of Veszprém it was destroyed or lost completely its significance as a stronghold. It was last mentioned in 1641 as a ruin.

The excavation and preservation of the monument was carried out simultaneously from 2003. Originally the archaeological research was led by Pál Rainer. First of all the south-eastern tower was excavated and restored, then the southern and the eastern curtain walls were unearthed.

The new research started in July 2013. The excavation works led by Dóra Hegyi and Szabolcs Balázs Nagy were coordinated by István Feld. The main aim of the research was to clarify the layout of the castle, which remained unknown except the east tower and the outer walls. This time the site was cut through with two long trenches (Fig. 32). We expected to find more buildings, but in vain. Only a part of the western curtain wall was found, which was completely buried prior the excavation (Fig. 35). At the same time, traces of a moat once divided the castle plateau in two parts were found with fragments of collapsed walls in it (Fig. 36).

During the excavation large amount of finds was collected: pottery (Fig. 33), stove tiles, animal bones, iron objects, etc. An elaborately carved antler handle decorated on both ends, on one of them with a cat or dragon-like figure (Fig. 34) is particularly worth to be mentioned. 
The results still arise more questions, e.g. where the inner buildings of the castle could have been, and whether the moat really divided the castle into two parts.

\section{Visonta (Hungary)}

\section{August-September 2013}

\section{With the Castle Museum of Eger (László Attila Nagy). ${ }^{6}$}

Visonta nowadays is a rather small village in North-Eastern Hungary with less than 1200 inhabitants. However, in the Middle Ages it played a much more significant role, indicated by the right of holding a weekly market (1323) and the designation oppidum (1445) - a settlement between villages and real towns, a central place in the micro-region. The results of the excavations, carried out in 2013 inside the still used church (Fig. 37), seem to verify this prominent position of the village in the 12th-13th centuries.

Before opening the first trenches (Fig. 38), our knowledge on the medieval period of the church was fairly poor. The first known charter mentioning it dates back to 1304 and reveals that it was the parish church of the Holy Cross. Later medieval sources do not uncover much information about the building itself. Although the present day church appears as a mostly Baroque building with some later additions, the polygonal apse and the eastern orientation implies its medieval origins.

Our expectations of an earlier church preceded the Gothic period proved to be right: after only one and a half week remains of a semicircular stone apse came to light (Fig. 39). Fortunately, the remains of the Romanesque apse were in relatively good state: above the wide stone foundation we observed the undermost stones of the wall as well. The wall was approximately $1 \mathrm{~m}$ thick and built of nicely carved ashlars on both the inner and outer side. In the south-western corner of the rectangular Romanesque nave a foundation of a stone pillar was discovered. This pillar foundation and the extraordinary width (more than $2 \mathrm{~m}$ ) of the western foundation of the nave together suggest that the Romanesque church was probably built with a western tower supported by the western wall and two inner pillars. The finds do not enable a precise dating but compared to analogies, this church might have been built in the 12th-13th centuries. According to the ashlar masonry, the size and the presumed western tower it must have been - from an architectural point of view - a rather significant church that implies either the regional significance of the settlement Visonta or the wealth of its patrons.

In the Gothic phase, most probably in the 15th century this old church was replaced by a new, approximately three times larger one. The walls of the Romanesque church were almost entirely pulled down, only the northern wall and foundation were retained and the ashlars of the demolished walls were reused. Five untouched rows of ashlars in the present day northern wall still represent the Romanesque period of the church.

Beside the remains of the early church the excavations uncovered several undisturbed (Fig. 40) and even more disturbed inhumation burials and disarticulated bones (Fig. 41). The earli-

6 The excavation was directed by Szabolcs Balázs Nagy (Eötvös Loránd University) and László Attila Nagy (Castle Museum of Eger). Participants were: Enikő Bilicz, András Fazekas, Anna Herbst, Szilvia Joháczi, Andrea Kocsis, Anna Mikesy, Zsófia Nádai, Sára Lantos, Emese Szalai, Tamás Szolnoki, Ágoston Takács, József Vigh (Eötvös Loránd University). 
est graves were discovered south of the Romanesque apse belonging to the graveyard before the Gothic period. Most of the undisturbed burials are from the 17th-19th centuries. A few of them preserved outstanding remains of the clothing of the dead. The most significant and spectacular one contained the overcloth, trousers, leather boots, a special triangular hat and the hair of the male deceased (Fig. 42). He was buried in a coffin decorated with small hexagram-shaped embossings probably in the 18th century.

The future evaluation of the burials, artefacts and every archaeological feature will lead to a much better understanding of the past of Visonta from the 12th to the 19th century.

\section{Drégely Castle (Hungary)}

\section{September 2013}

With the Béla Dornyai Museum, Salgótarján (Krisztián Zandler). ${ }^{7}$

The castle of Drégely is one of the most famous strongholds of the Hungarian history due to its heroic defence in 1552 when 150 defenders faced an army of 10.000 and withstood them for four days.

The systematic archaeological research of the castle started already in the 1990s and was led by Tamás Majcher for a long time. This year, however, we were invited to continue the research started by him at the remains of the artillery tower built at the southern end of the castle, prior to its restoration and reconstruction planned to be done in 2014.

The castle of Drégely is a relatively small stronghold situated cca. $4 \mathrm{~km}$ from the village Drégelypalánk, in the forest area, on the top of a $444 \mathrm{~m}$ high mount (Fig. 43). The castle was built in the second half of the 13th century and consisted only of a tower and a courtyard with a palace wing attached to the surrounding stone curtain walls. Its owners changed from high nobility to King and finally, in 1438 it was donated to the archbishop of Esztergom. Then a large lower castle with new curtain walls and two northern semicircular towers was built.

Drégely was never of huge importance but during the Ottoman wars it was used as a border castle. Yet before the Turkish attack of 1552 a new artillery tower was attached south of the earlier castle protecting the medieval entrance. This, however, did not help too much: Drégely was occupied, renewed by the Ottomans and in 1593 was taken back.

In September 2013 we uncovered the whole artillery tower (Fig. 44). This was built on the rock, partially carved into it. The tower had irregular layout resembling a quadrant. There were two embrasures - one facing the south-eastern slope of the mount (Fig. 45) and the other looking south. The thickness of the walls varied between $2.8 \mathrm{~m}$ on the eastern and 3.8 $\mathrm{m}$ on the western side. The northern wall - on the most protected façade - was only $70 \mathrm{~cm}$ "thick".

The tower had two entrances. The smaller one was a $0.6 \mathrm{~m}$ narrow corridor cut into the rock (Fig. 46) and bending from the north-eastern corner of the tower led toward the 16th century main entrance of the outer bailey of the castle. The other entrance was much wider. It

7 The excavation was led by Maxim Mordovin with co-directors Mária Vargha and Krisztián Zandler. Participants were: Dániel Budai (Péter Pázmány Catholic University), Andrea Kocsis, Ágoston Takács and Nóra Ujhelyi (Eötvös Loránd University). 
was created within the thinner northern wall and served for lifting the artillery and ammunition up to the tower. On the inner side of this wall two carved stones of the gates (Fig. 47) and the stone foundation of the crane were found. There was also a special niche for the stove in the north-western corner, within the wall of the tower (Fig. 48). The removed debris contained a large number of stove tile fragments datable to the 16th century.

Many interesting objects were collected during the excavation, including lead bullets, buckles, coins, etc. Fragment of a medieval candlestick from the 15th century (Fig. 49) and a 13th century ring are the most notable finds.

The present archaeological research has slightly modified the widely accepted dating of the tower. Now it seems that its construction took place between 1544 - the fall of Nógrád and 1552, but it was not destroyed during the siege, on the contrary, it remained in use up until the whole castle was abandoned, most likely by the middle of the 17th century.

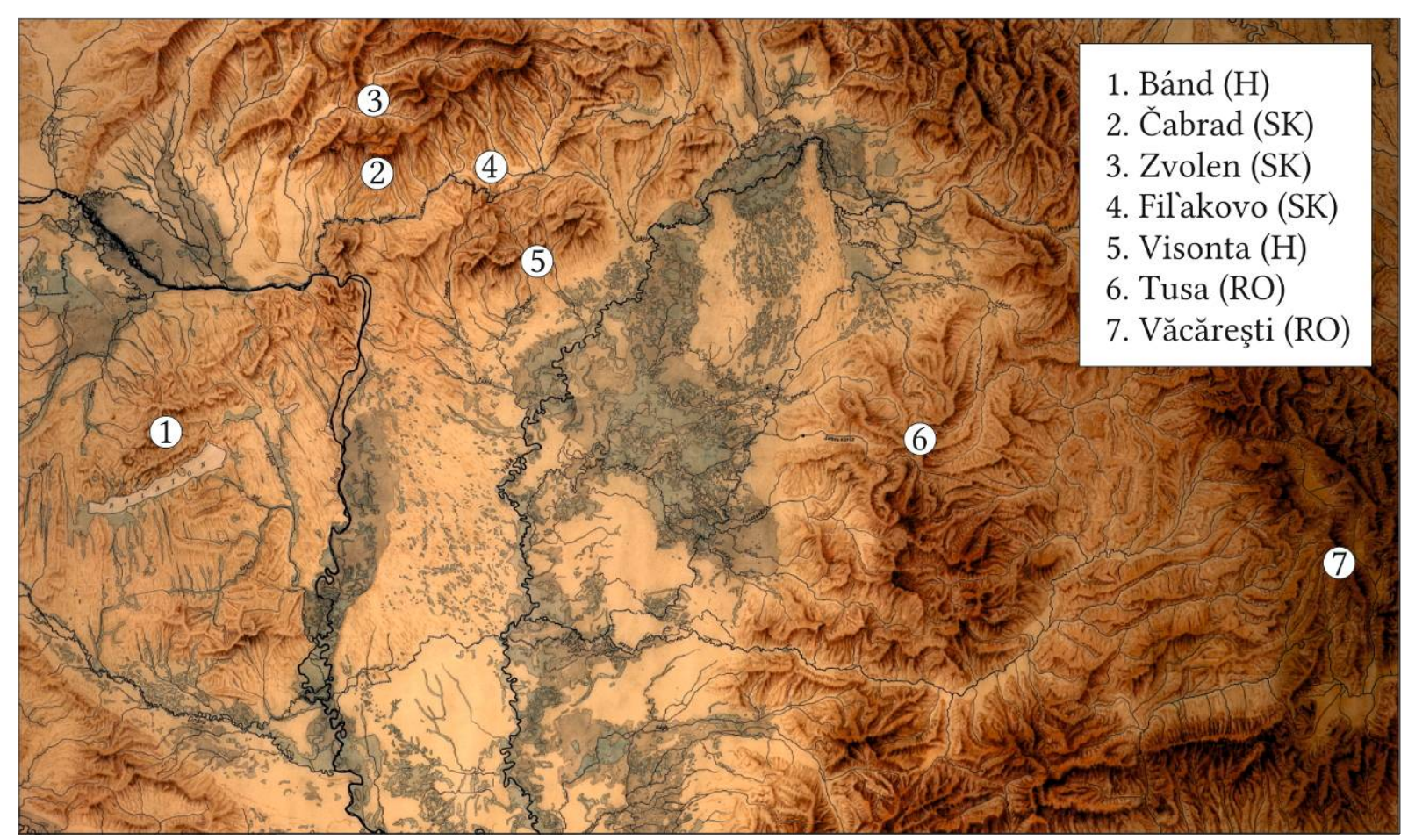

Fig. 1. Excavations carried out by or with the cooperation of the Department of Hungarian Medieval and Early Modern Archaeology in 2013. 


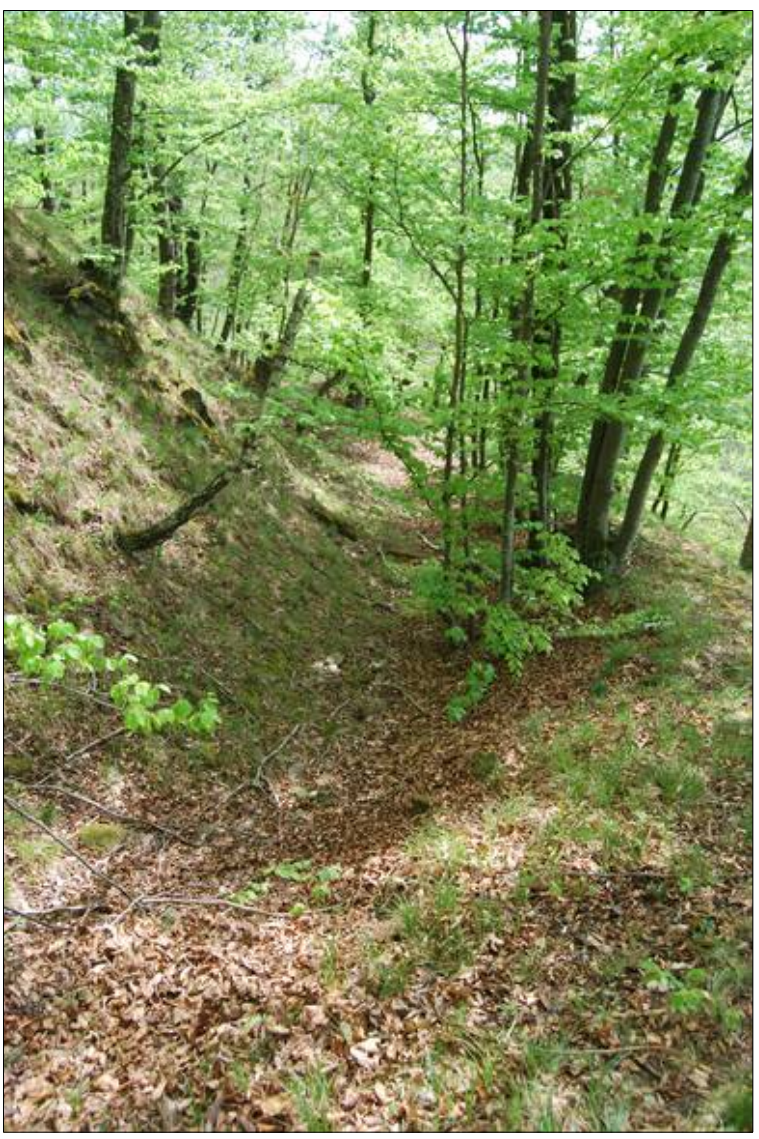

Fig. 2. The third defence line of the castle of Tusa.

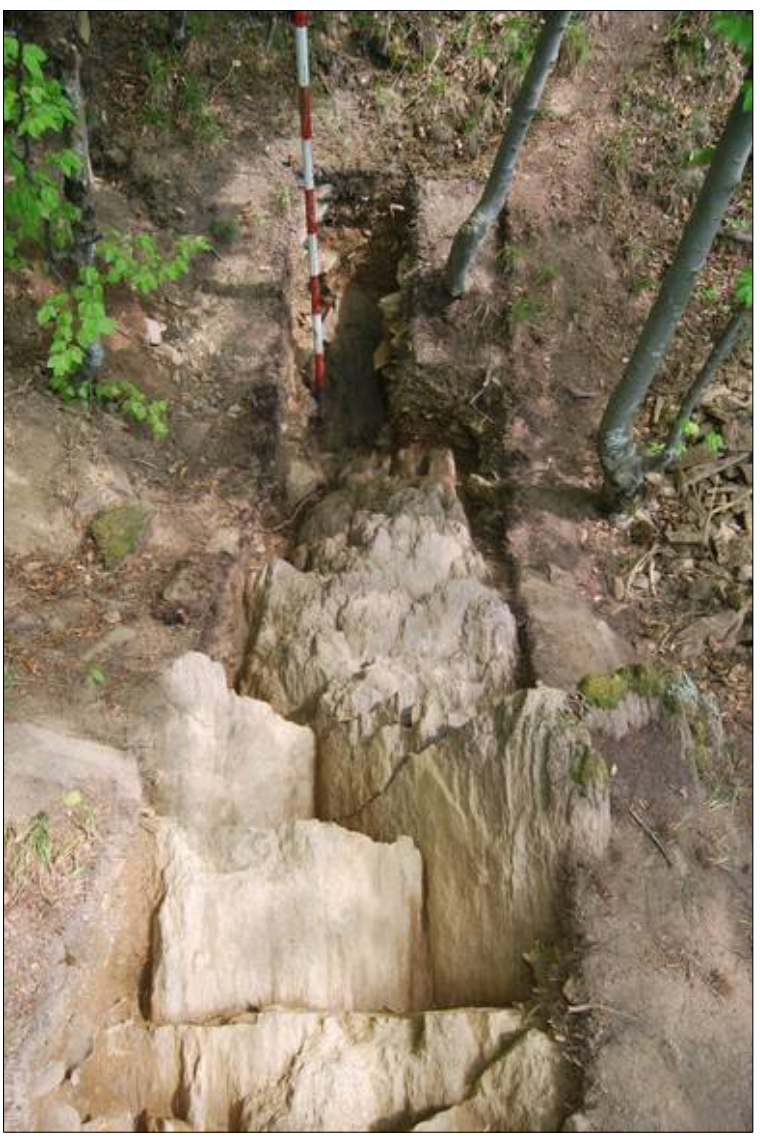

Fig. 3. The excavated section of the ditch at Tusa.

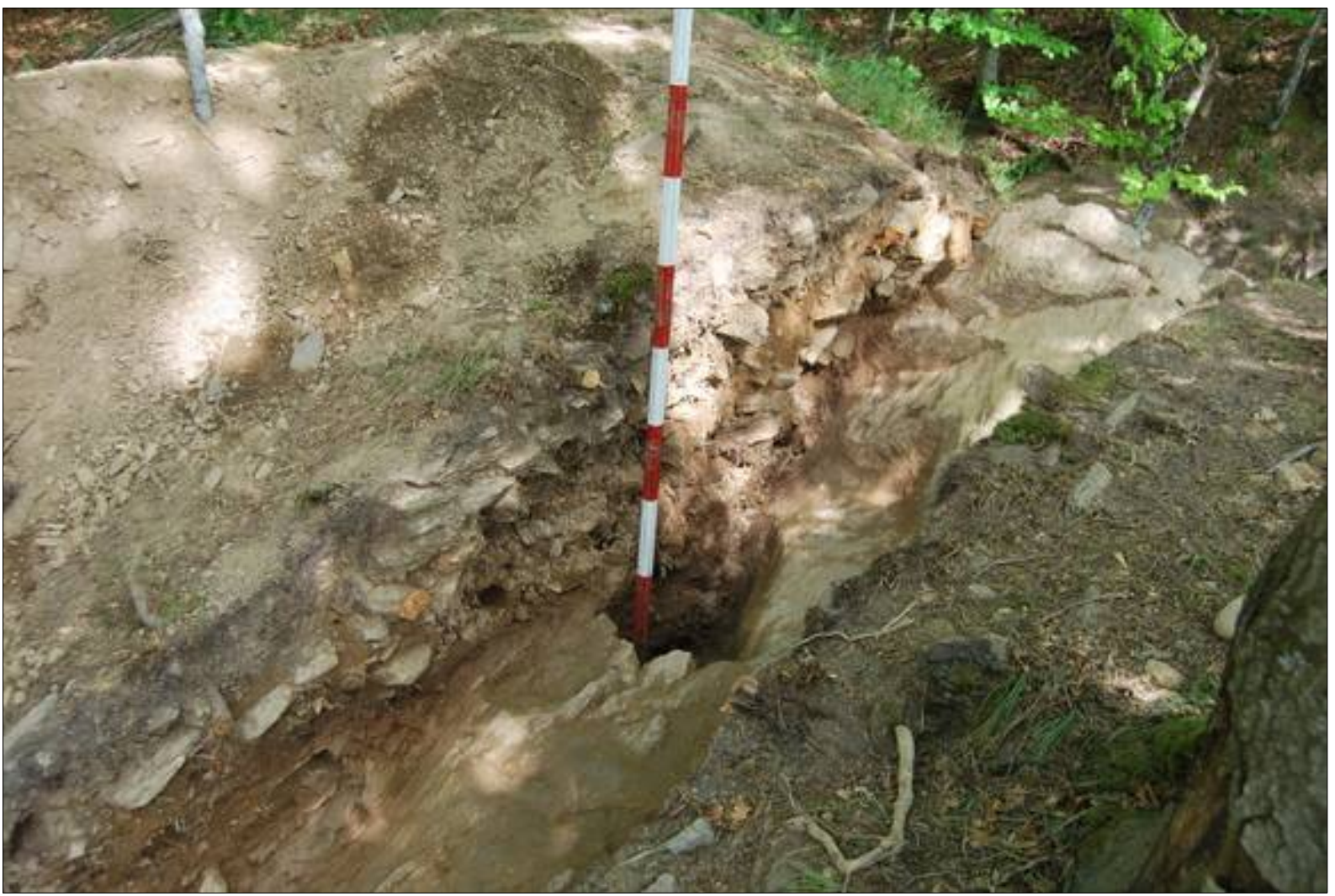

Fig. 4. The dry stone wall and a post hole of the third defence line at Tusa. 


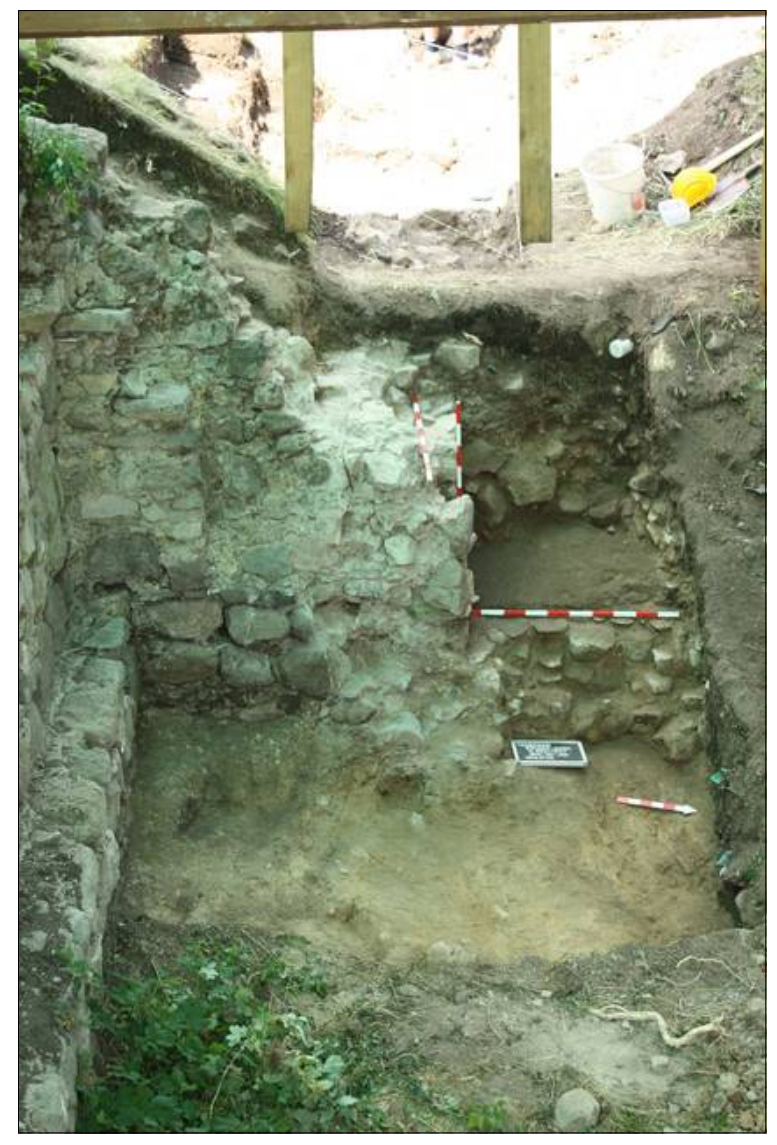

Fig. 5. The excavated remains of the western entrance of the cellar at Văcăreşti.

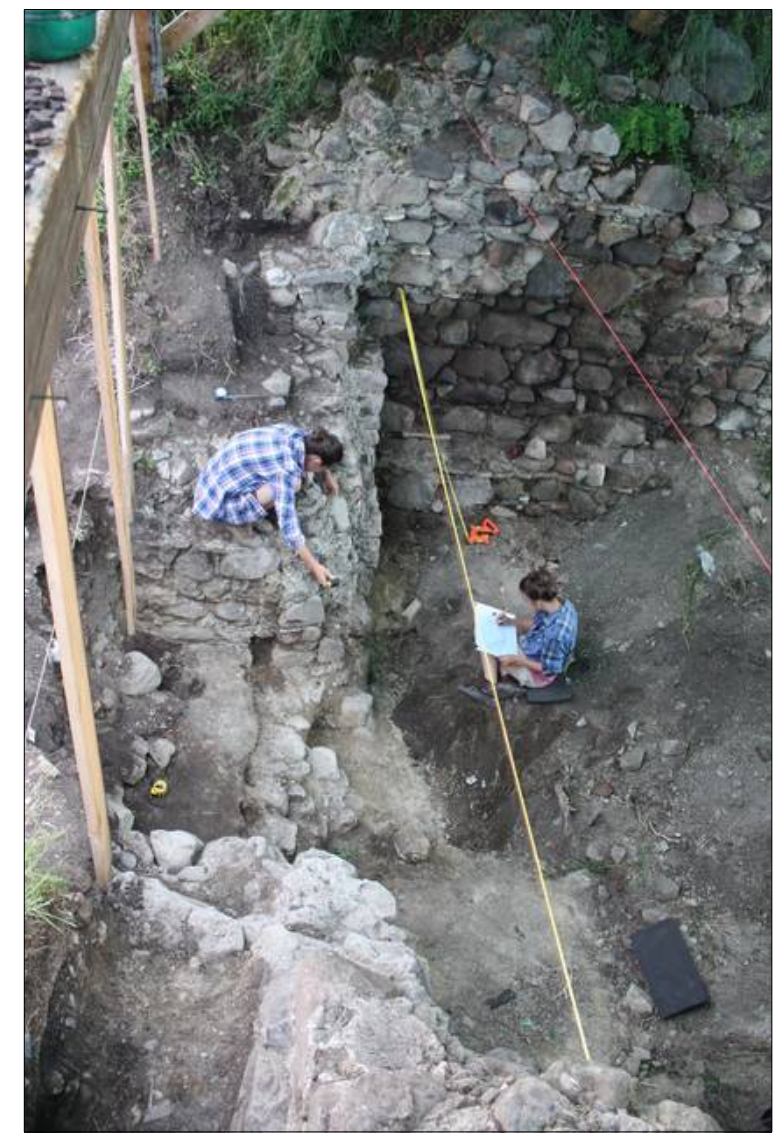

Fig. 6. The documentation of the western walls of the cellar at Văcăreşti.

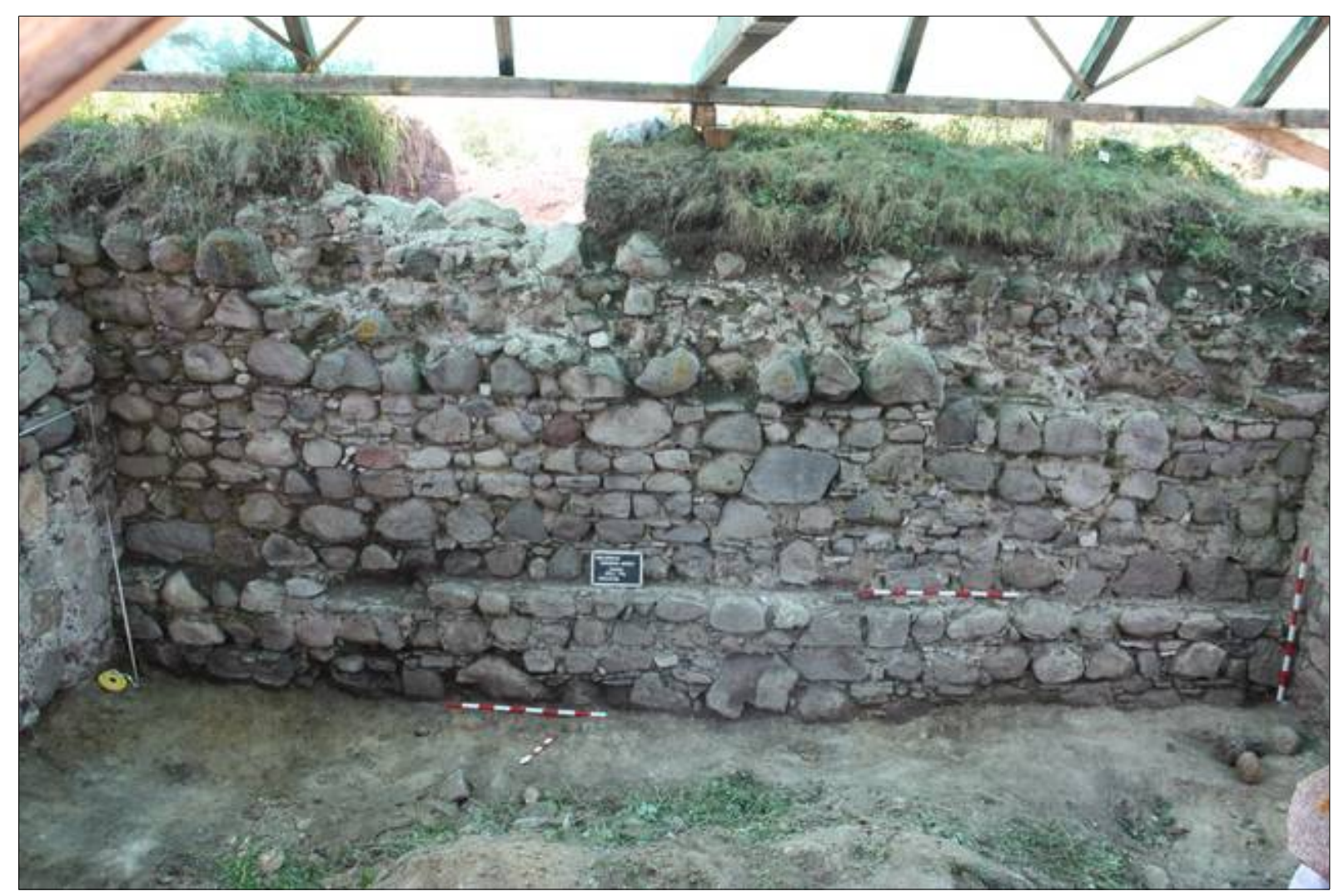

Fig. 7. The southern wall of the cellar at Văcăreşti. 


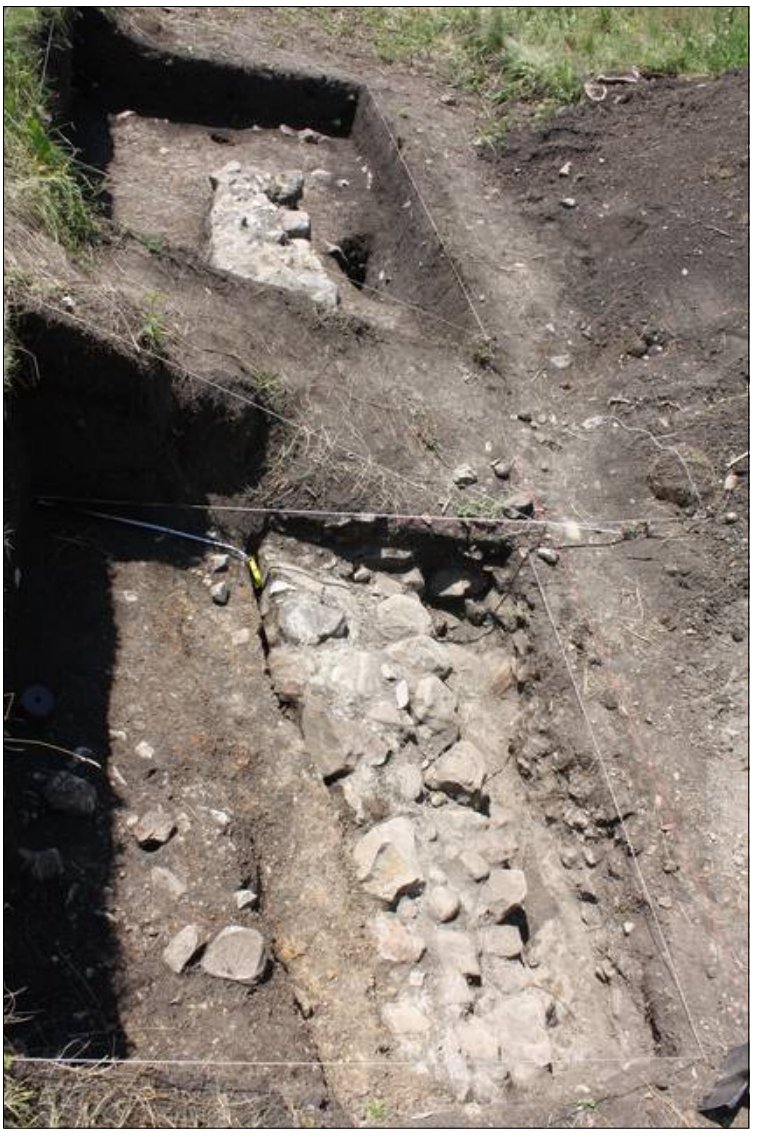

Fig. 8. The southern wall of the entrance corridor at Văcăreşti.

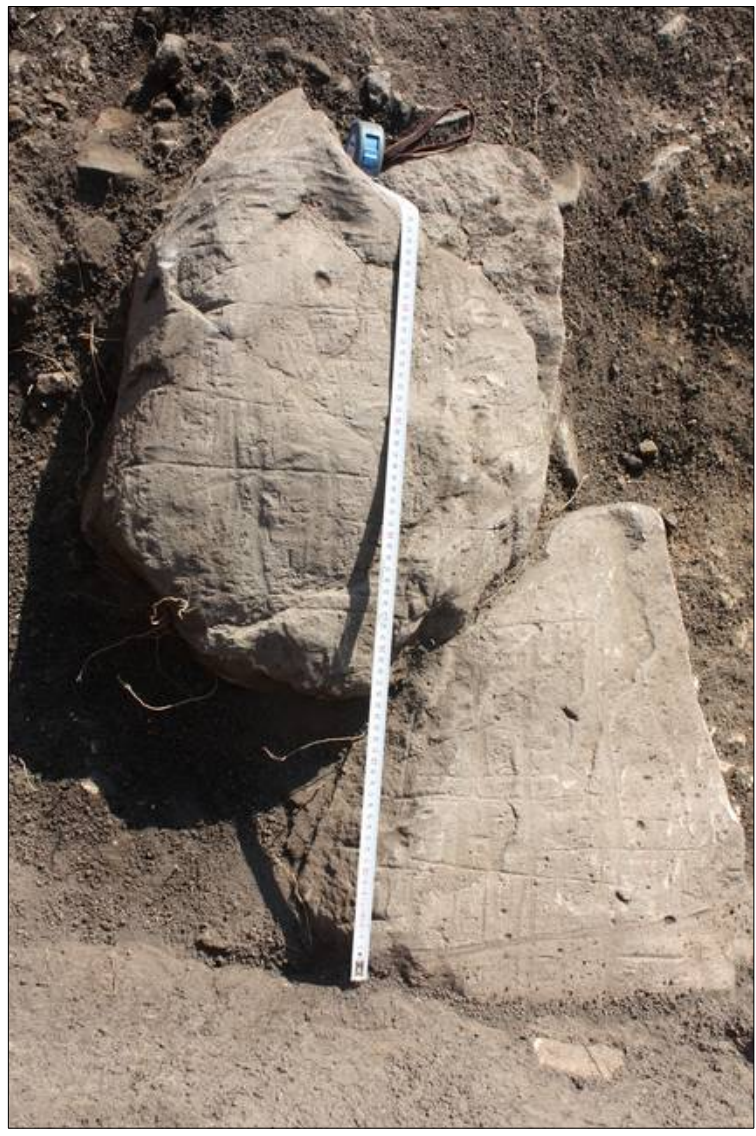

Fig. 9. Stones with plough traces on their surface at Văcărești.

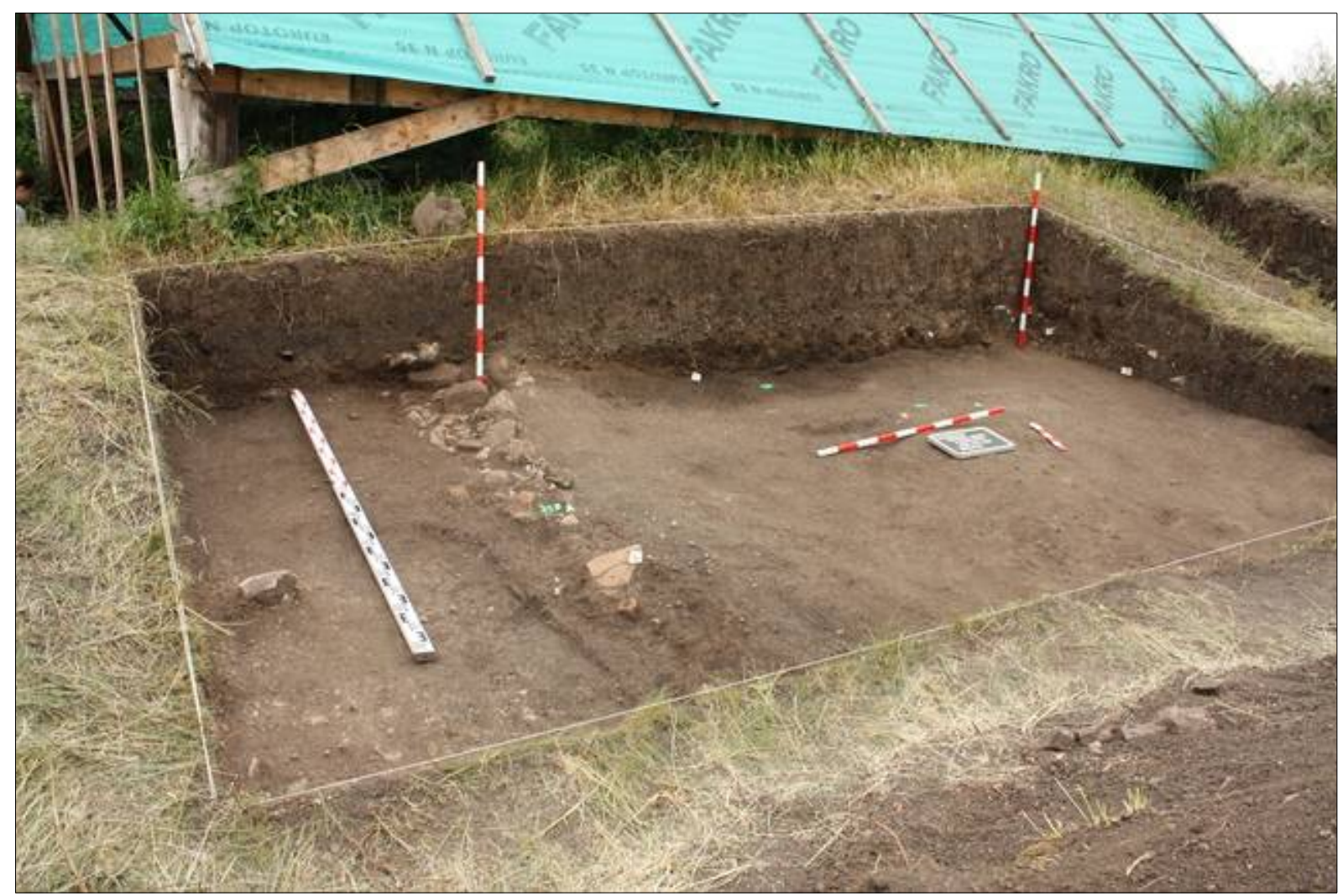

Fig. 10. The foundation wall of the timber framed building attached south of the cellar (Văcăreşti). 


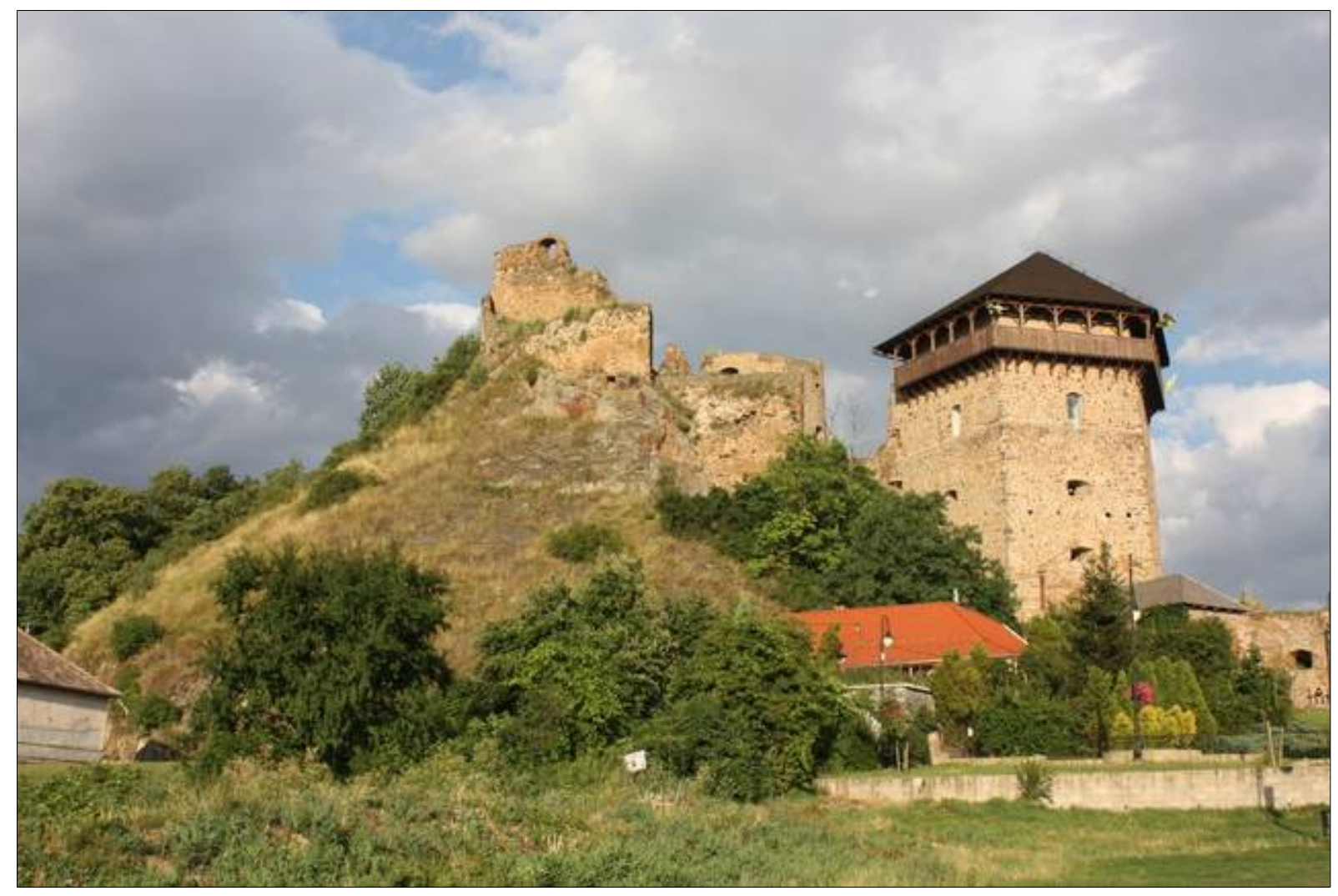

Fig. 11. The castle of Filakovo.

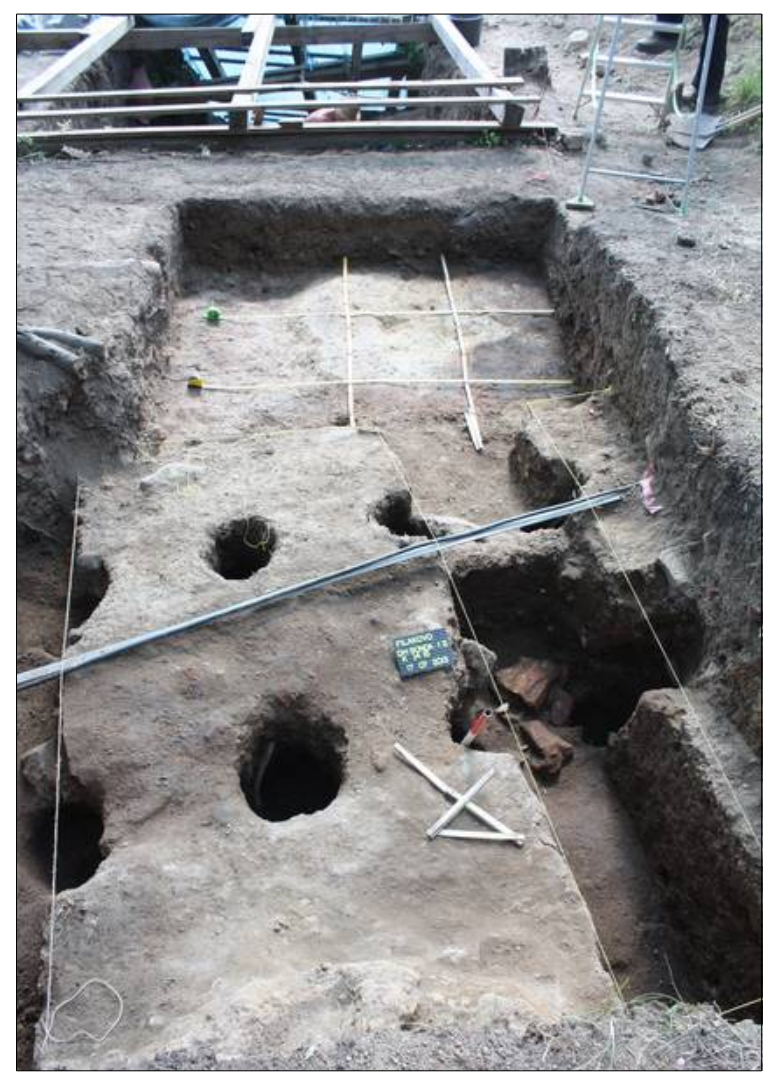

Fig. 12. Remains of the 17th century palisade at Filakovo.

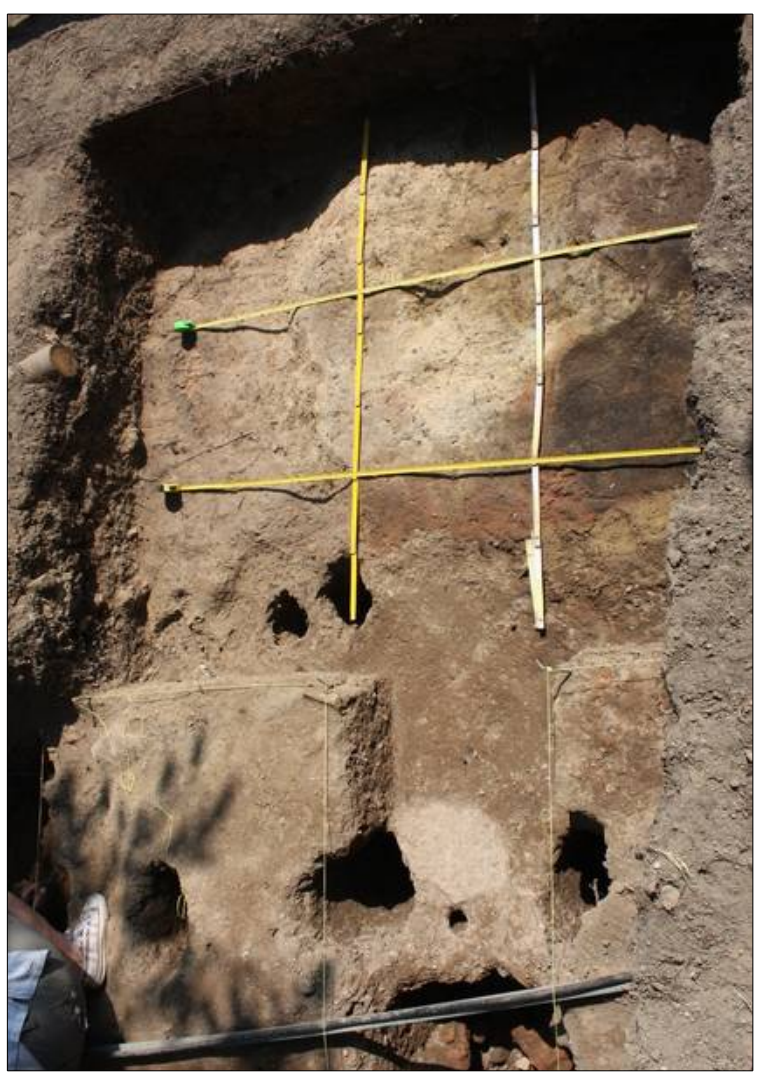

Fig. 13. Fragment of the floor of a building attached to the palisade (Filakovo). 


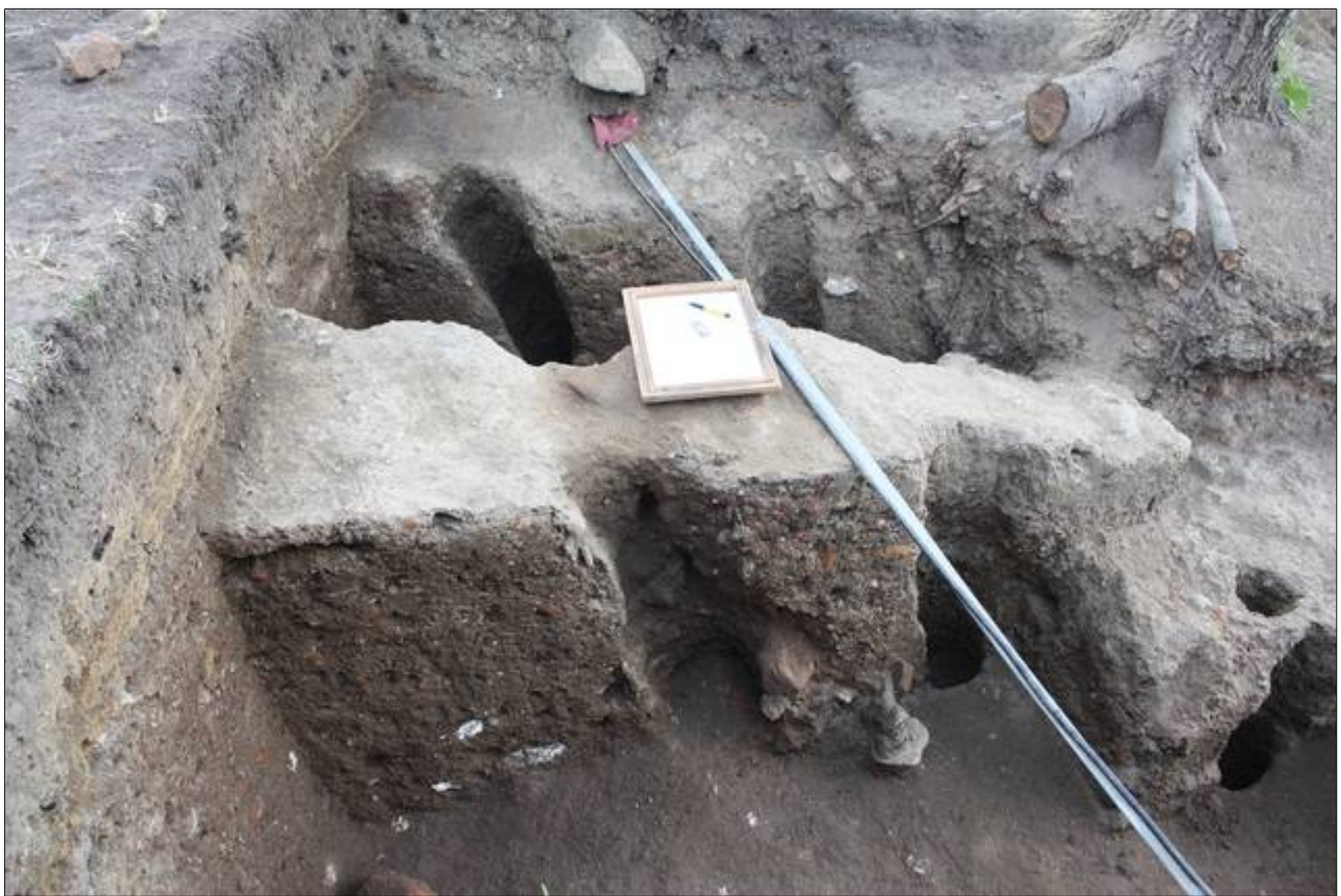

Fig. 14. Trenches cut through the palisade (Filakovo).

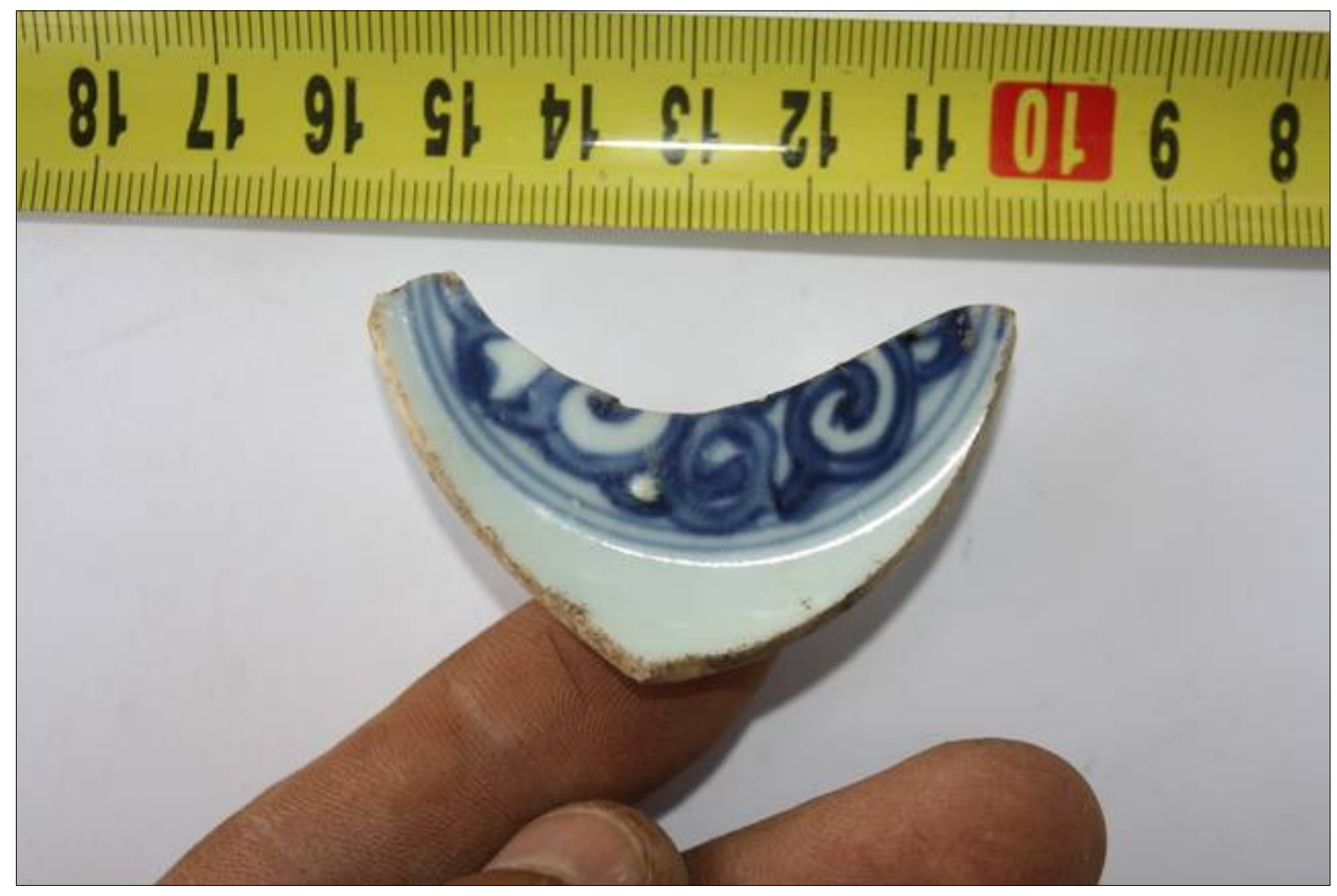

Fig. 15. Fragment of a china cup from the late 16th century layers (Filakovo). 


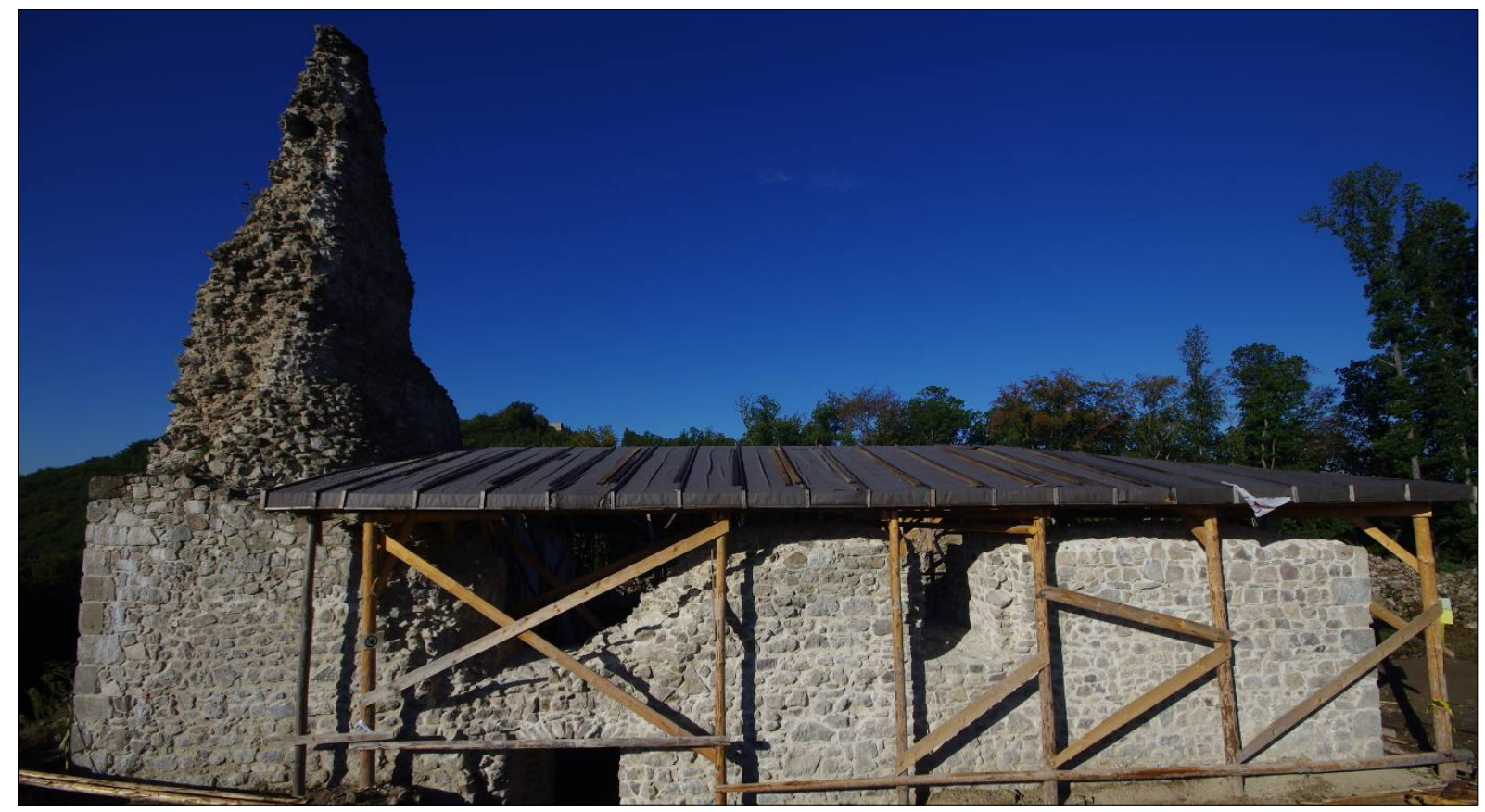

Fig. 16. Keep of the Deserted Castle at Zvolen.

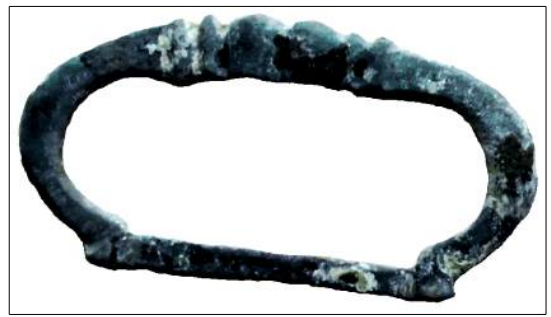

Fig. 17. 13th century buckle from Zvolen.

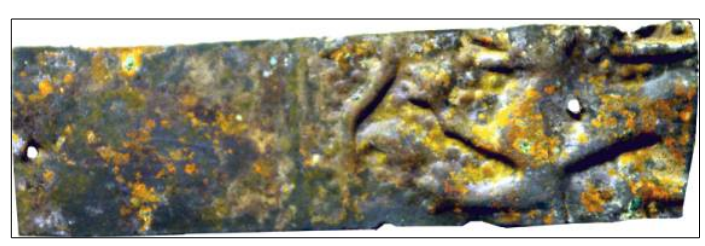

Fig. 18. Medieval bronze fitting with a dragon (?) from the excavations at Zvolen.

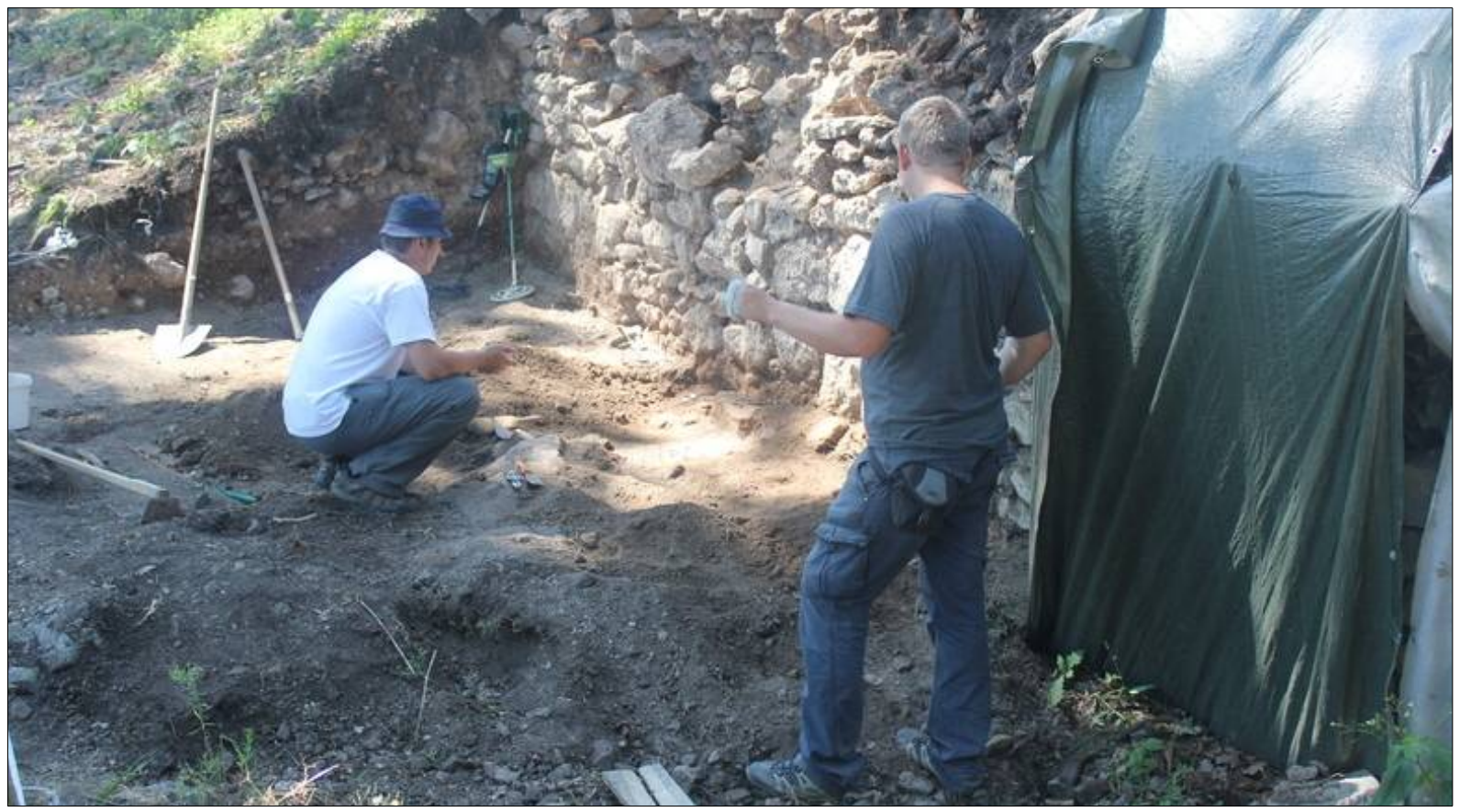

Fig. 19. Ján Beljak and Dominik Repka at the excavation (Zvolen). 


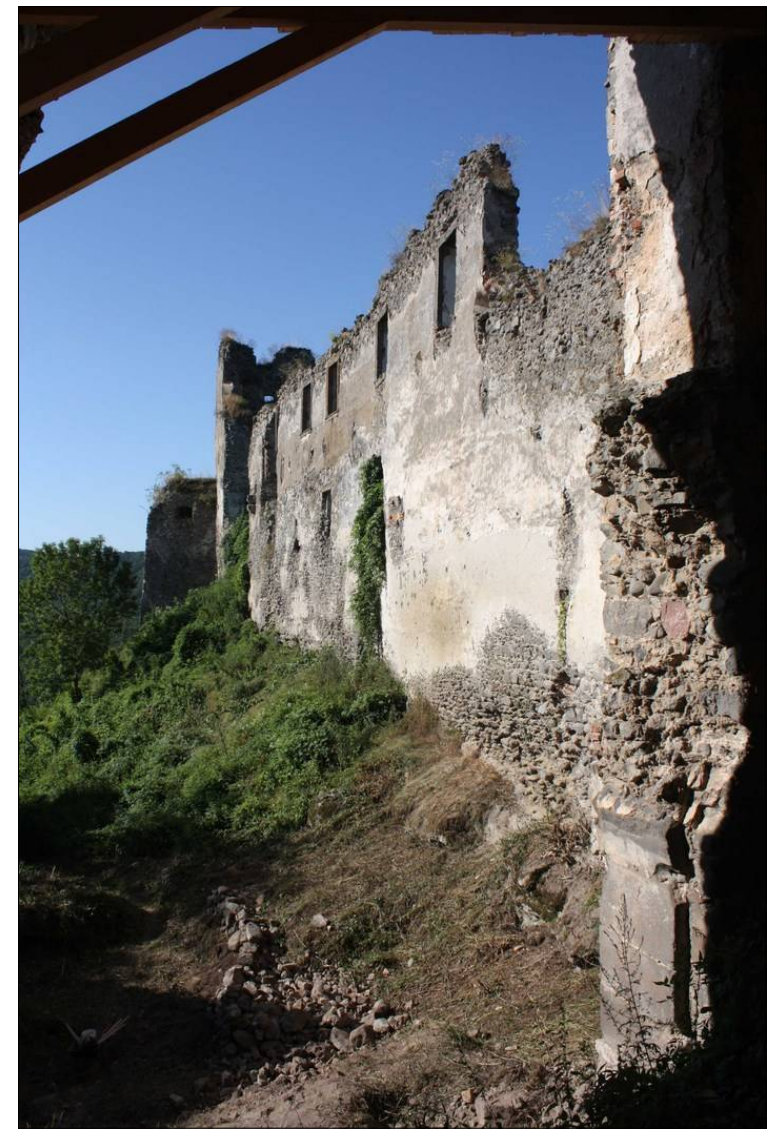

Fig. 20. The castle of Čabrad' from the third gate tower.

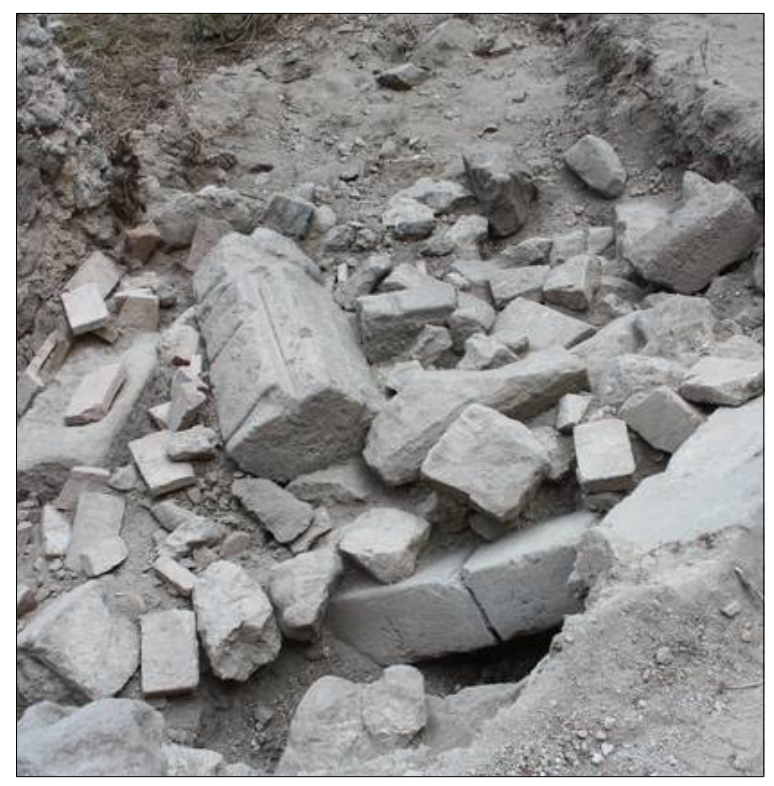

Fig. 23. The fallen fragments of the gate in the second trench (Čabrad').

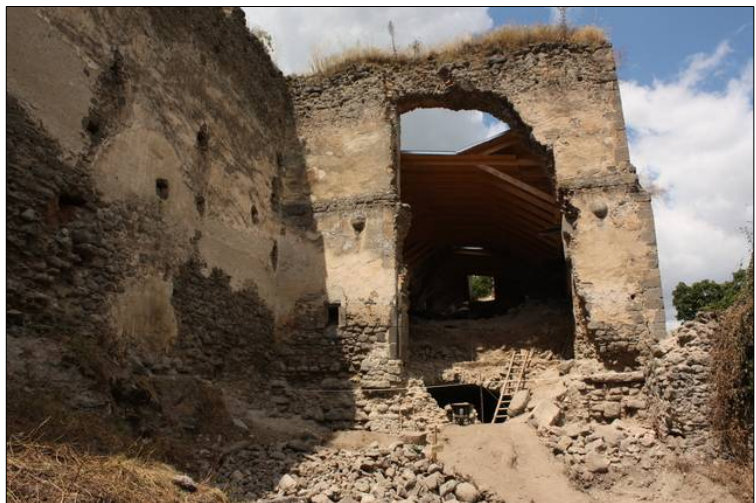

Fig. 21. The excavation site at the third gate tower (Čabrad).

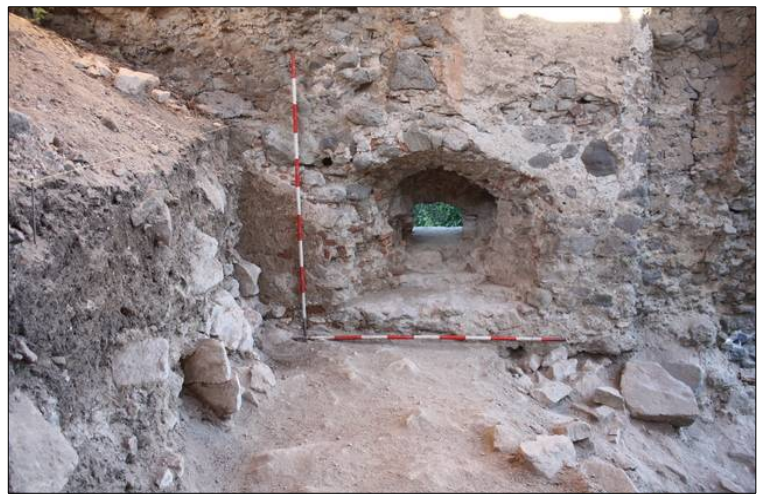

Fig. 22. Embrasure at the eastern wall of the gate tower (Čabrad').

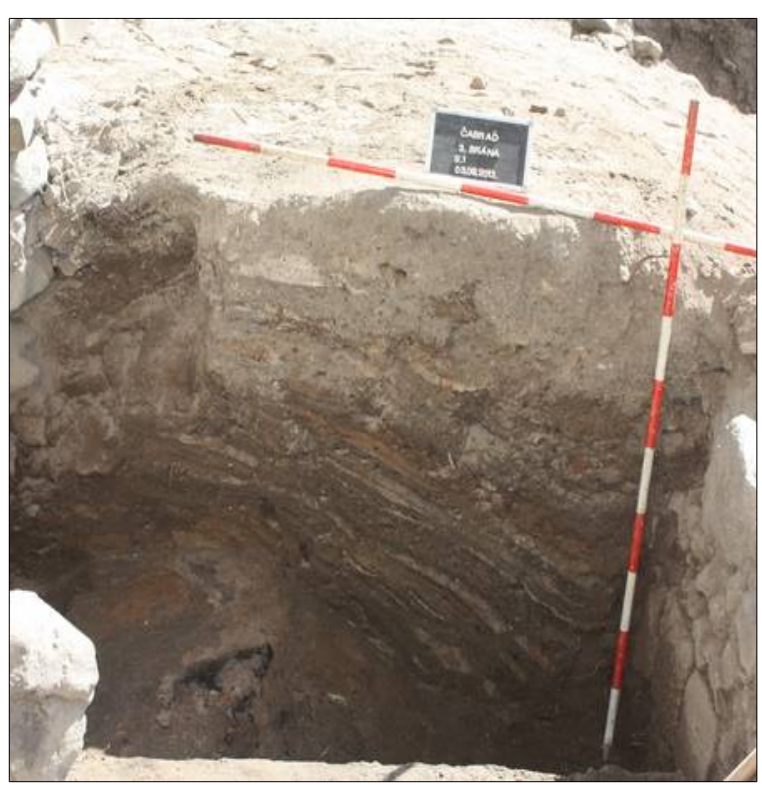

Fig. 24. The filling layers of the drawbridge-pit in the first trench (Čabrad'). 


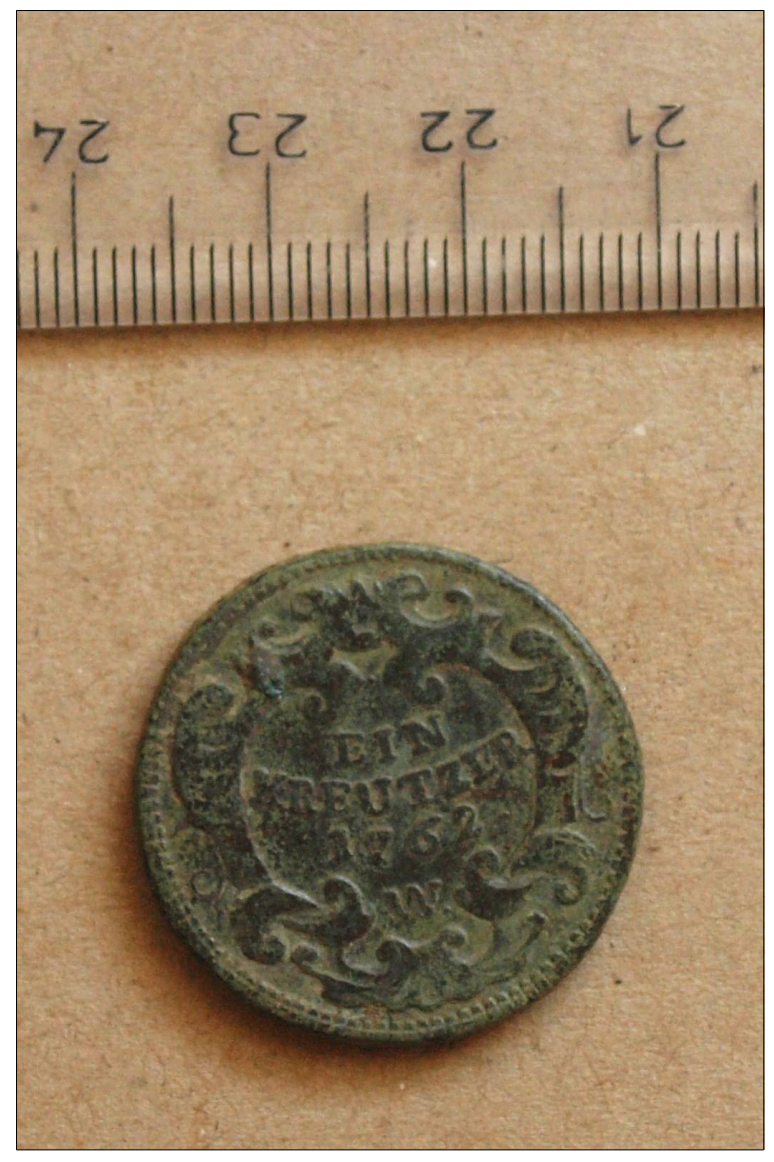

Fig. 25. One Kreutzer from 1762 (Čabrad).
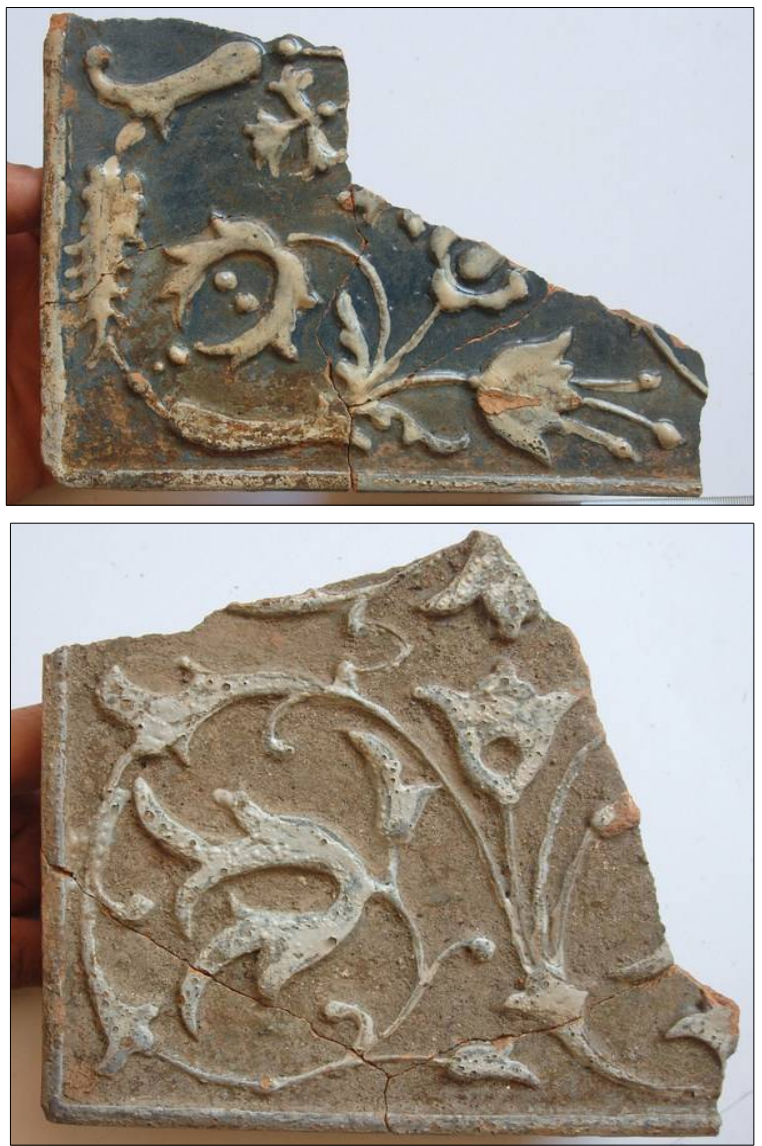

Fig. 26-27. 17th century stove tiles made in the socalled habán style from the drawbridge-pit (Čabrad).

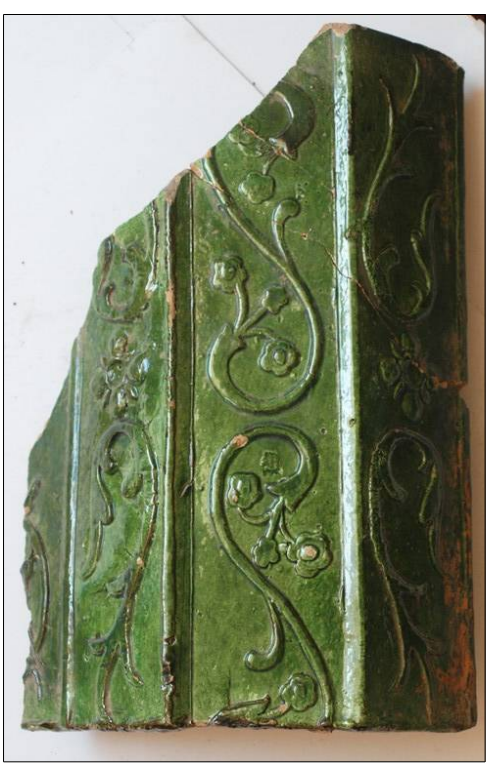

Fig. 28. Late renaissance stove tile from the drawbridge-pit (Čabrad).

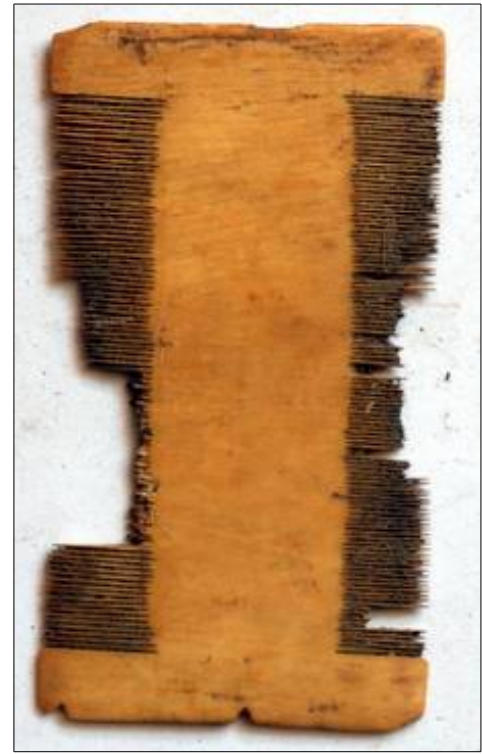

Fig. 29. 18th century antler comb from the drawbridge-pit (Čabrad').

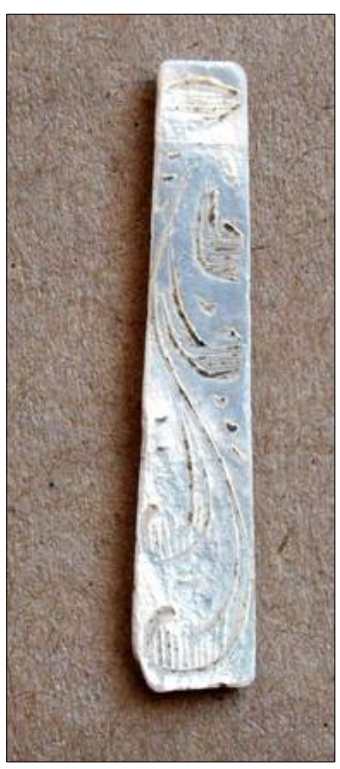

Fig. 30. A fragment of incised shell intarsia from a fork handle (Čabrad'). 


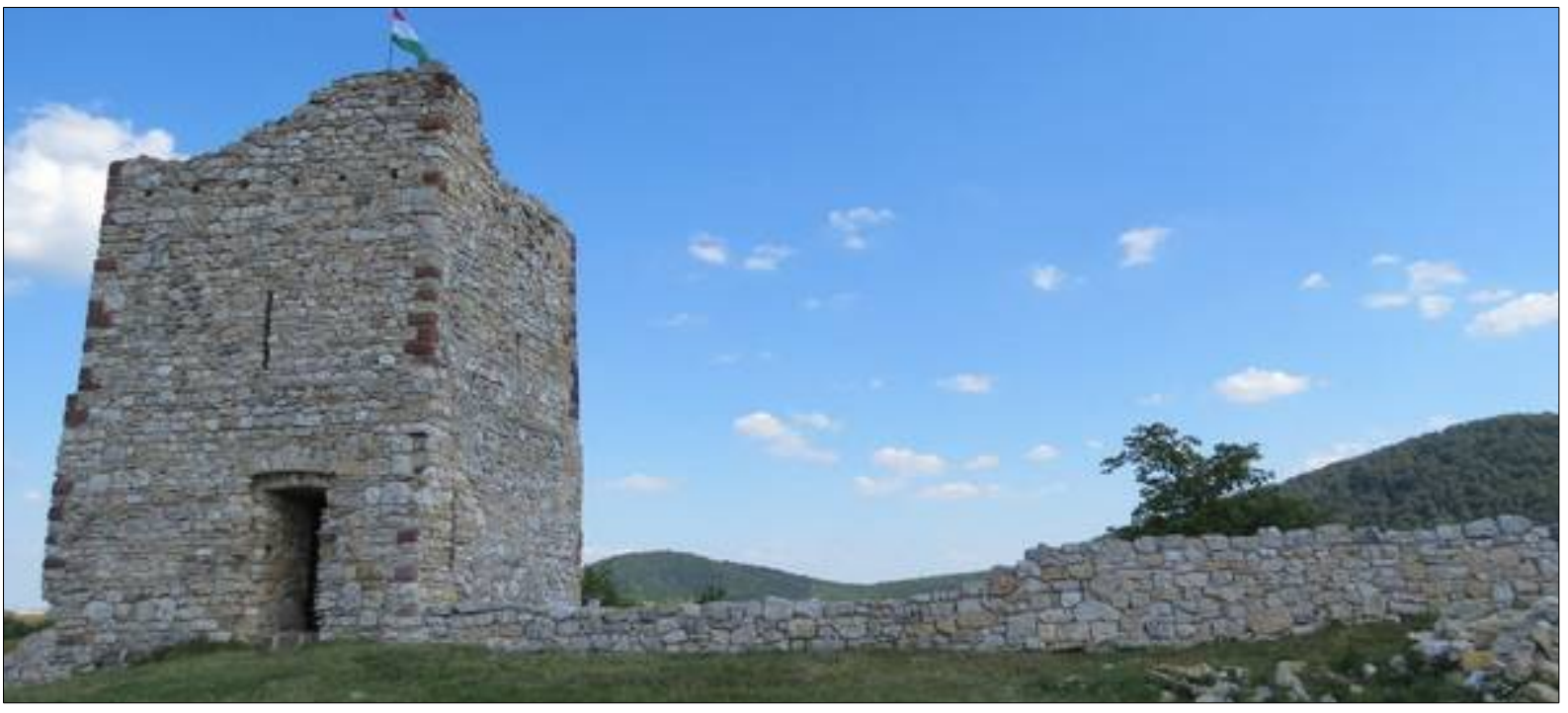

Fig. 31. Castle of Esseg at Bánd.

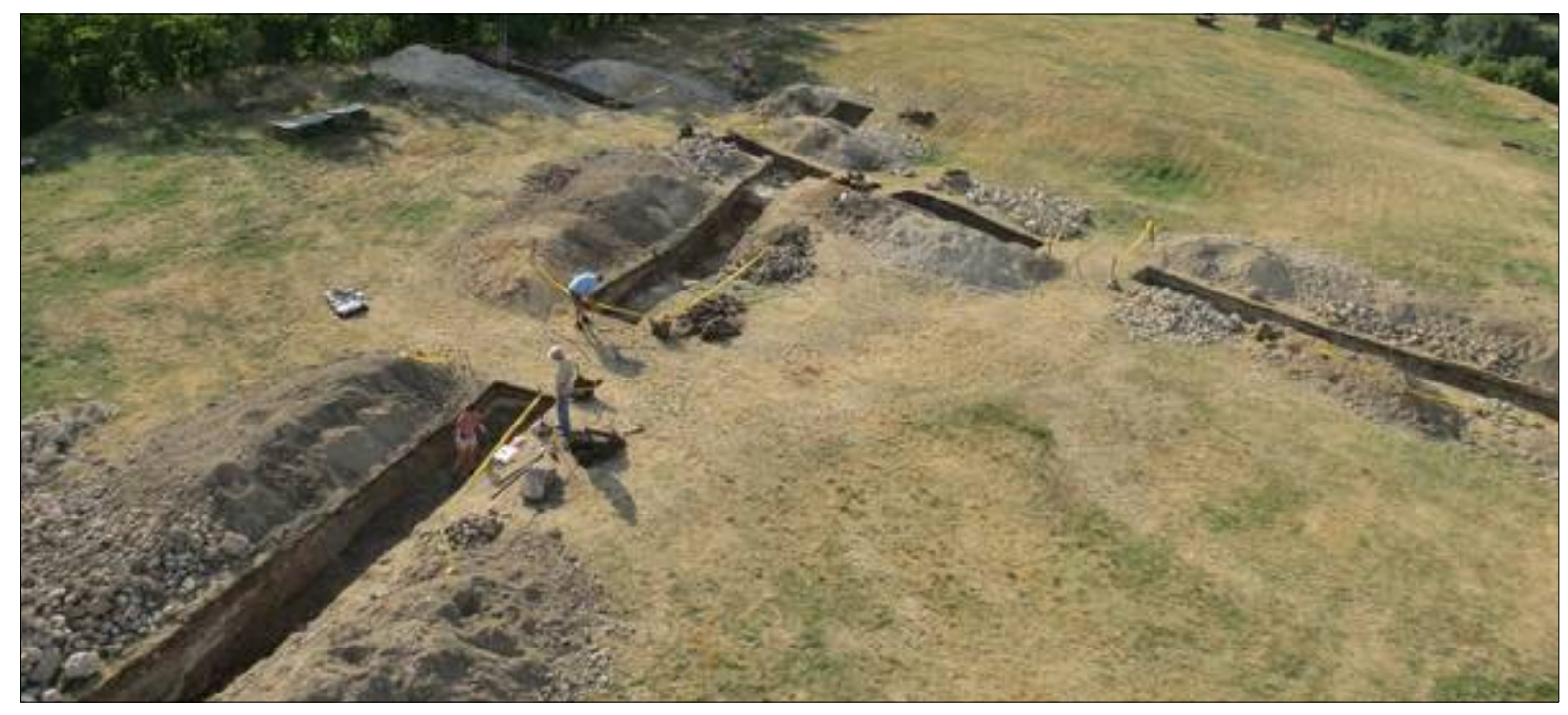

Fig. 32. Aerial view of the excavation at Bánd - Essegvár.

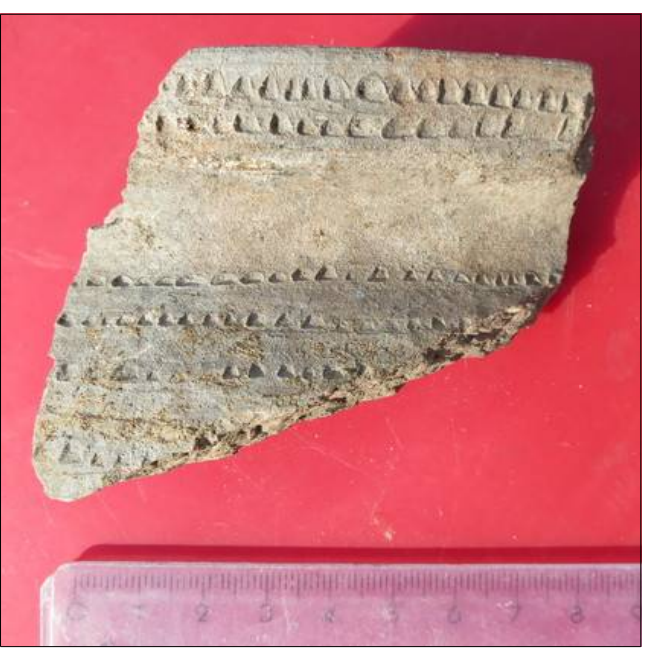

Fig. 33. A 13th century pot fragment from the castle (Bánd)

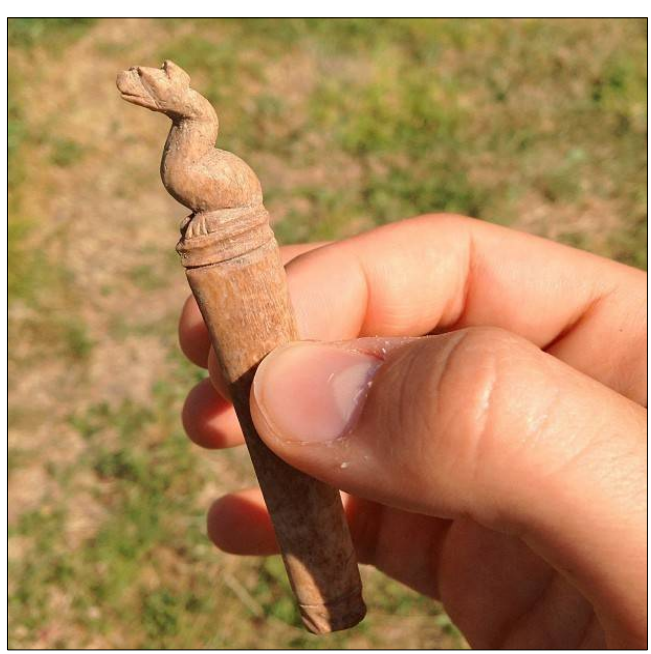

Fig. 34. Carved antler knife handle (Bánd). 


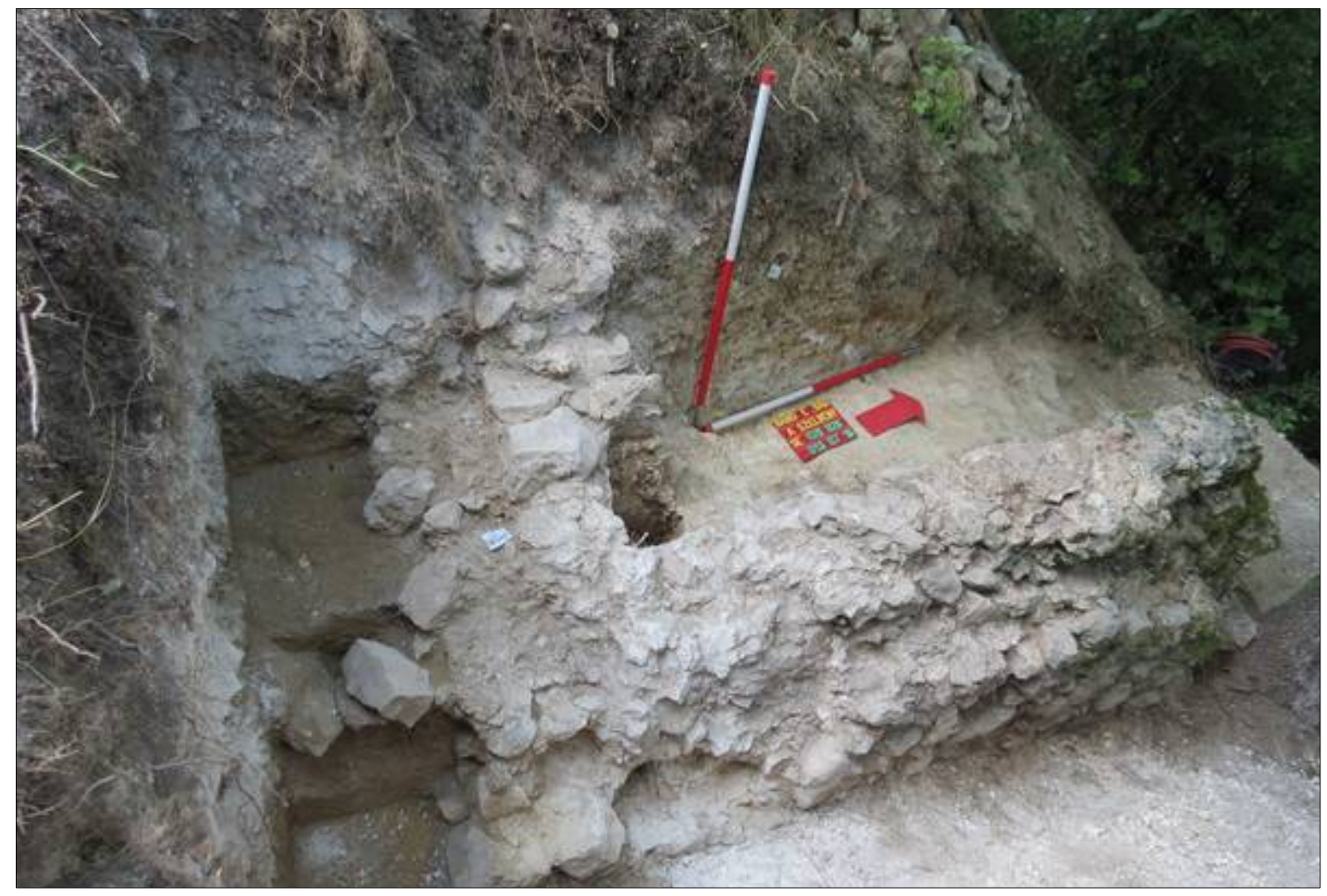

Fig. 35. Excavated building fragments at Essegvár (Bánd).

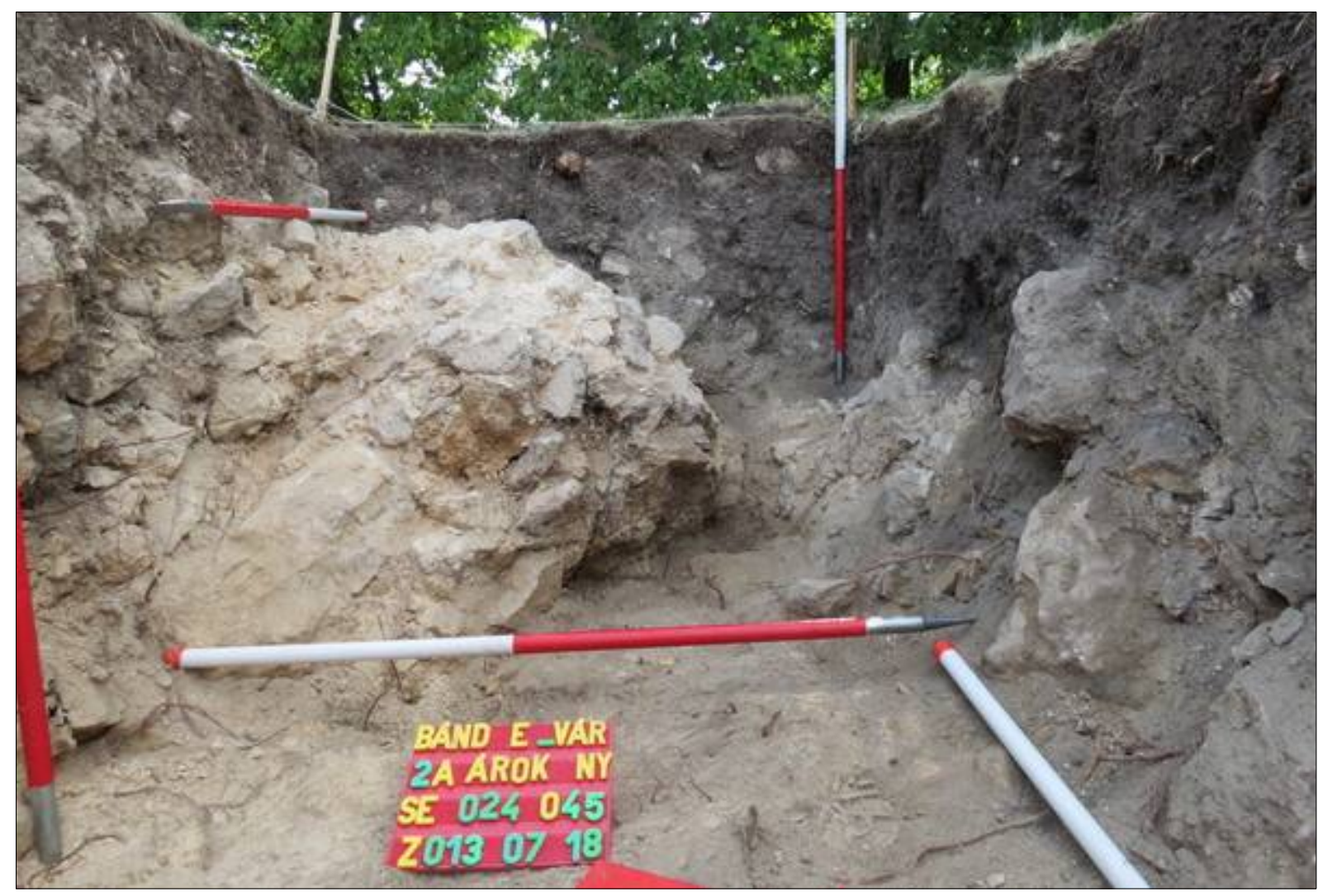

Fig. 36. Collapsed wall fragments at Essegvár (Bánd). 


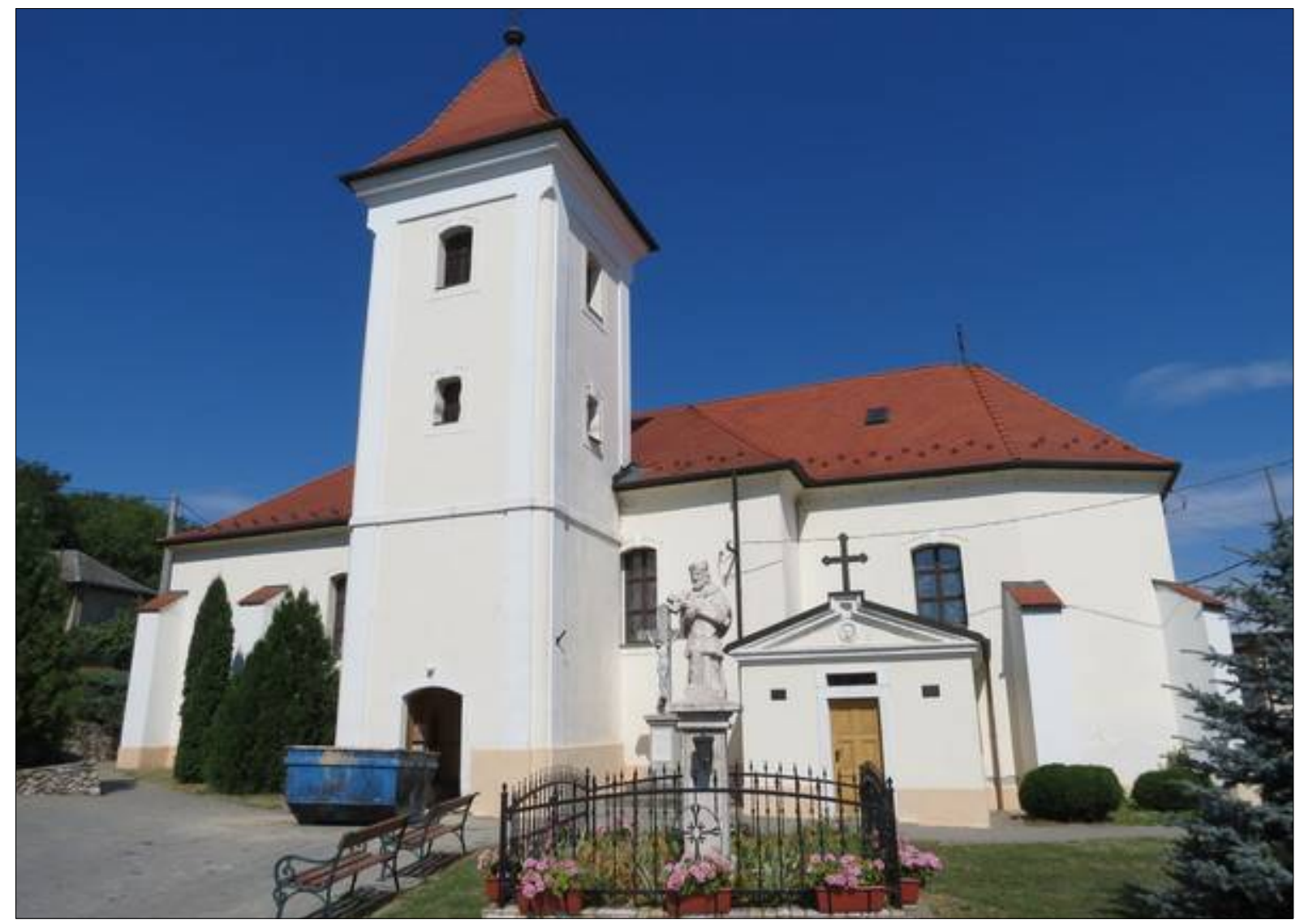

Fig. 37. The parish church of Visonta.

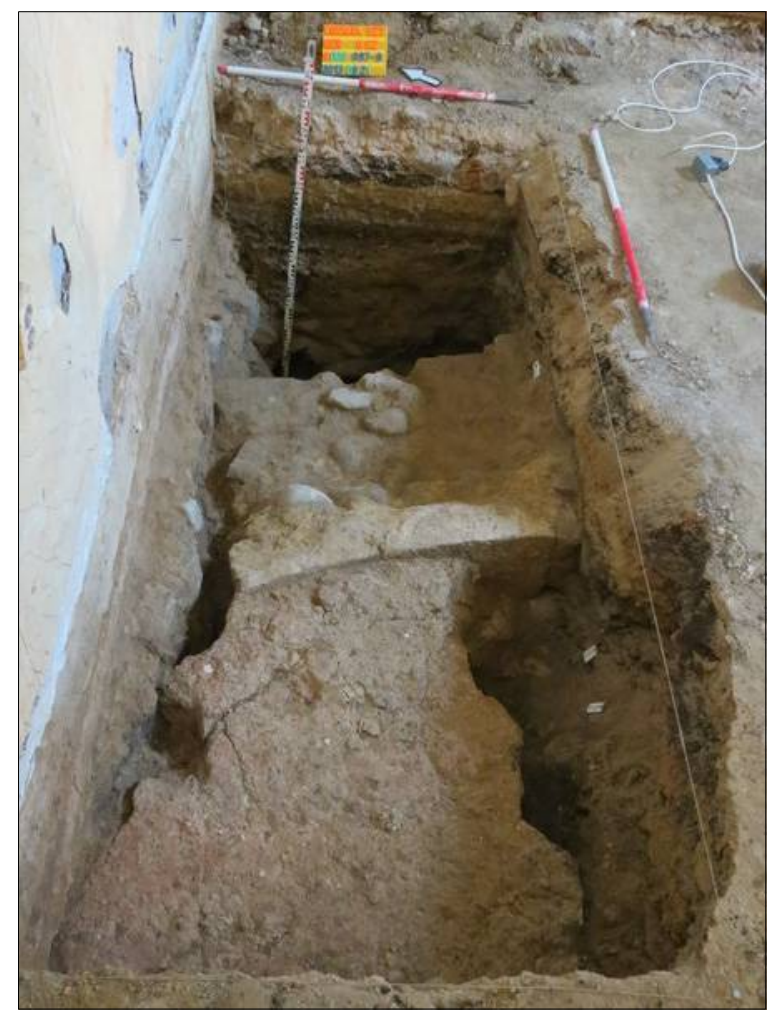

Fig. 38. The excavation inside the church (Visonta).

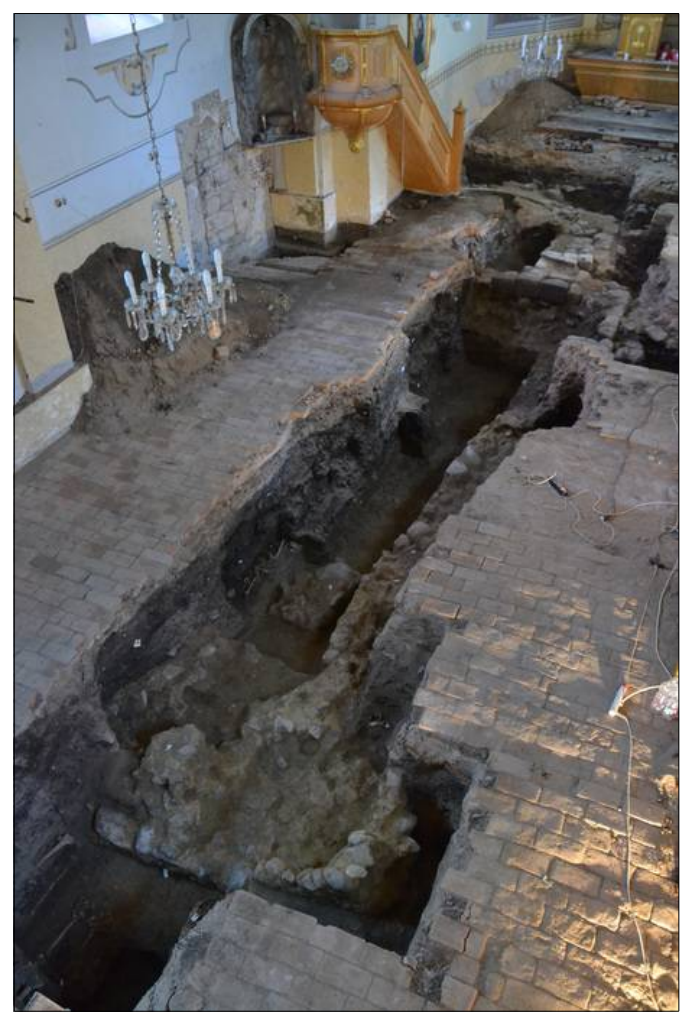

Fig. 39. Remains of the Romanesque apse (Visonta). 


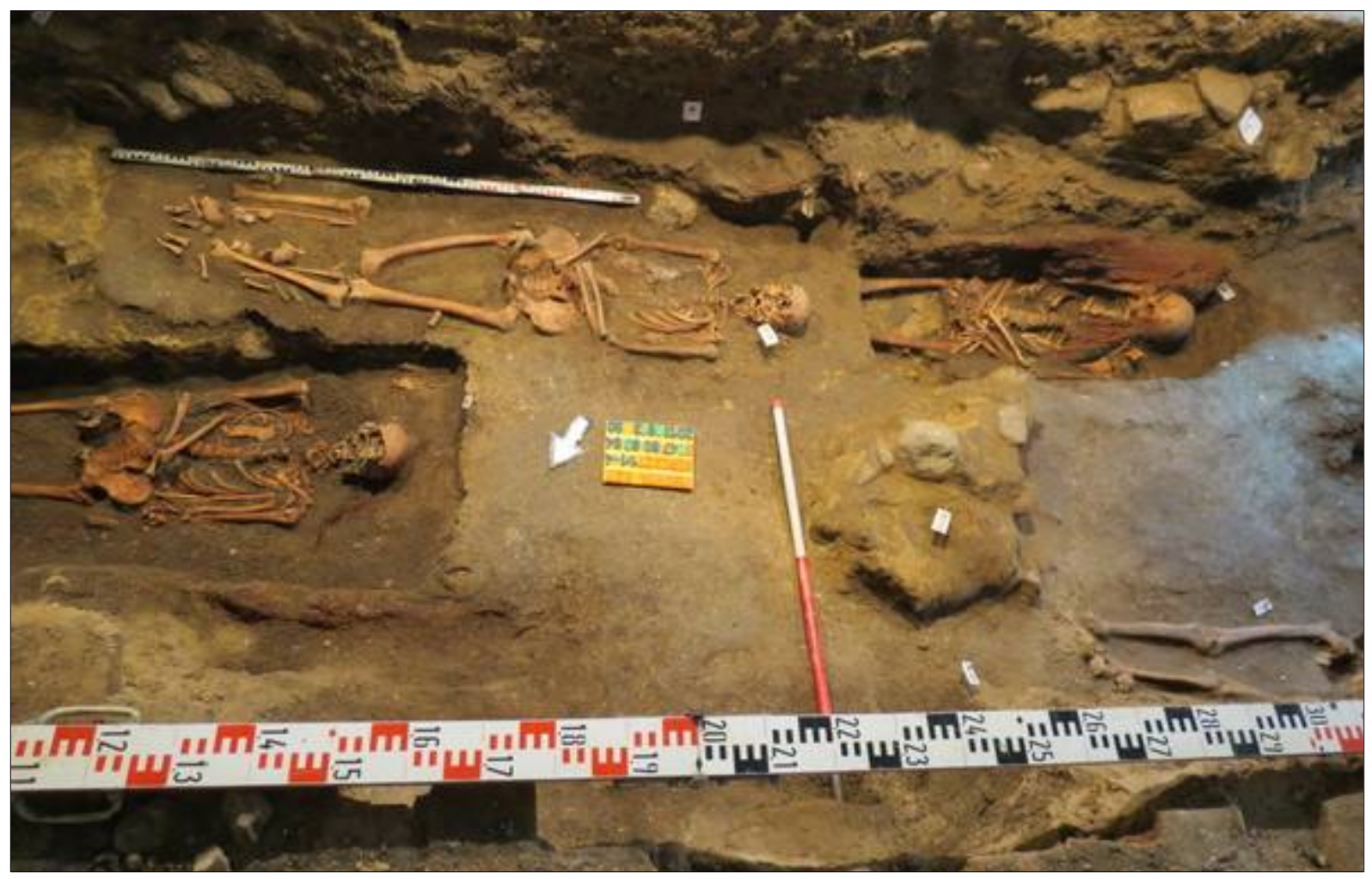

Fig. 40. Unearthed 18th century burials inside the church of Visonta.

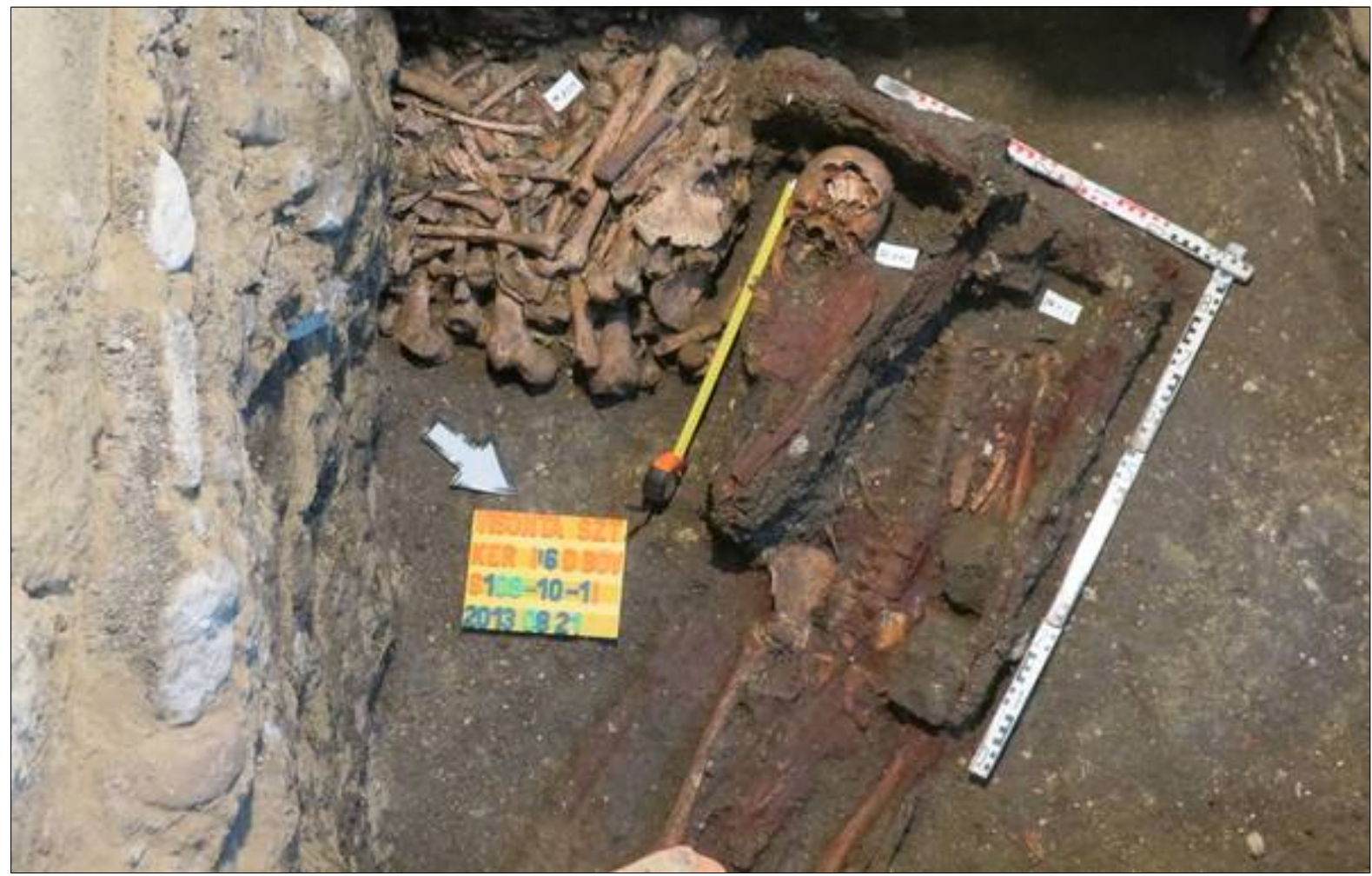

Fig. 41. Two burials in wooden coffins with secondarily replaced human bones (Visonta). 


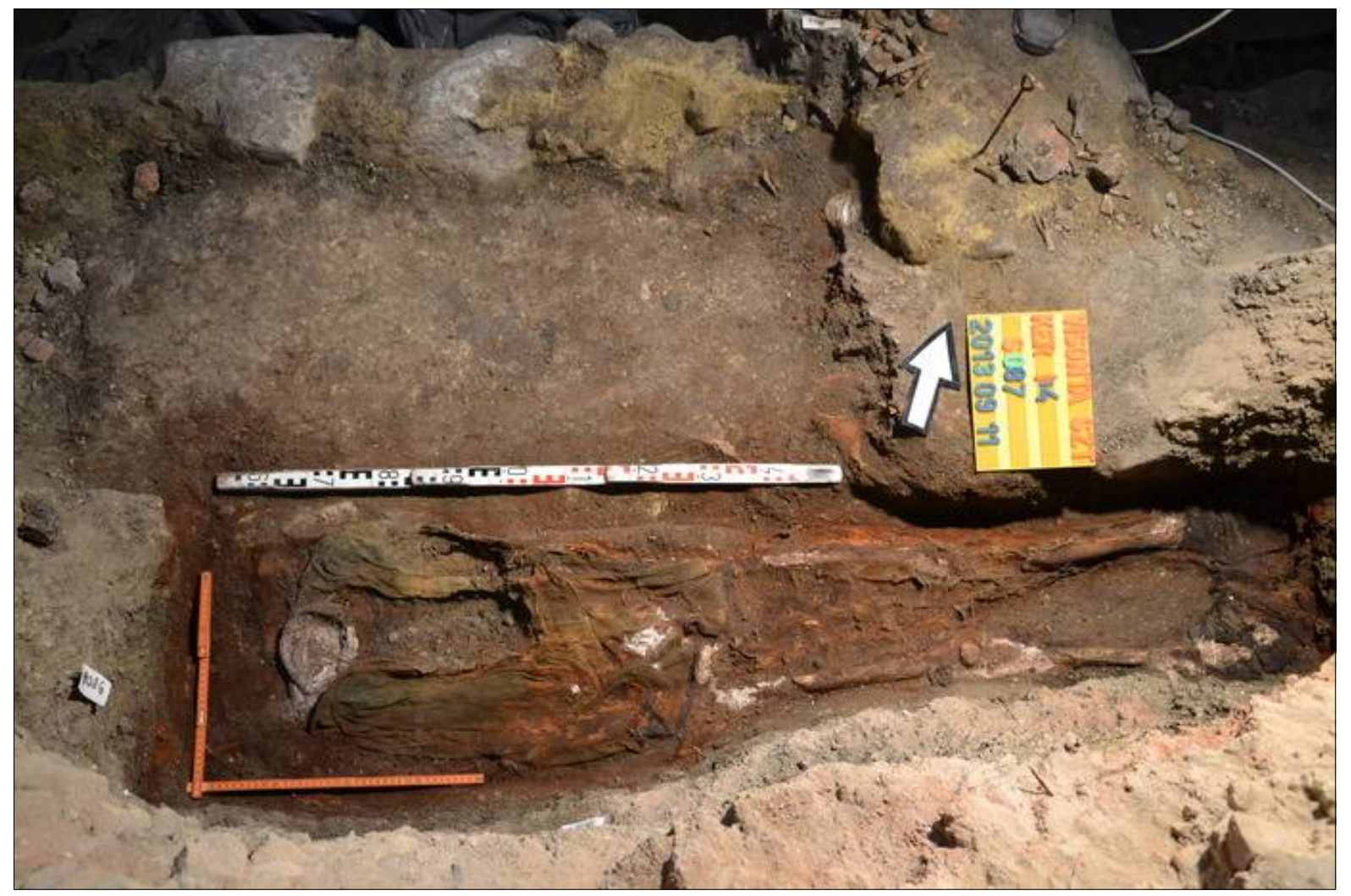

Fig. 42. The best preserved 18th century male burial in the church of Visonta.

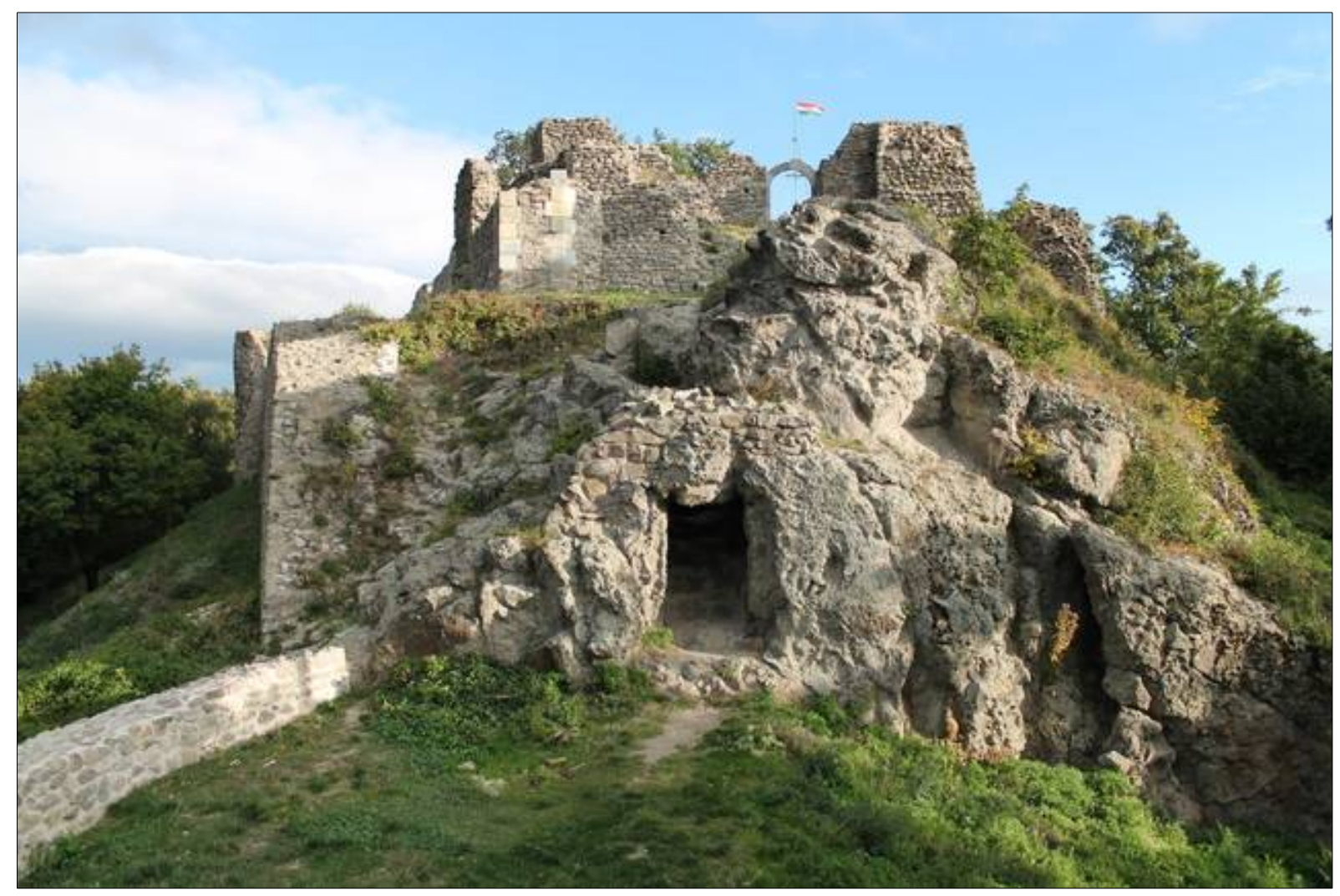

Fig. 43. The castle of Drégely. 


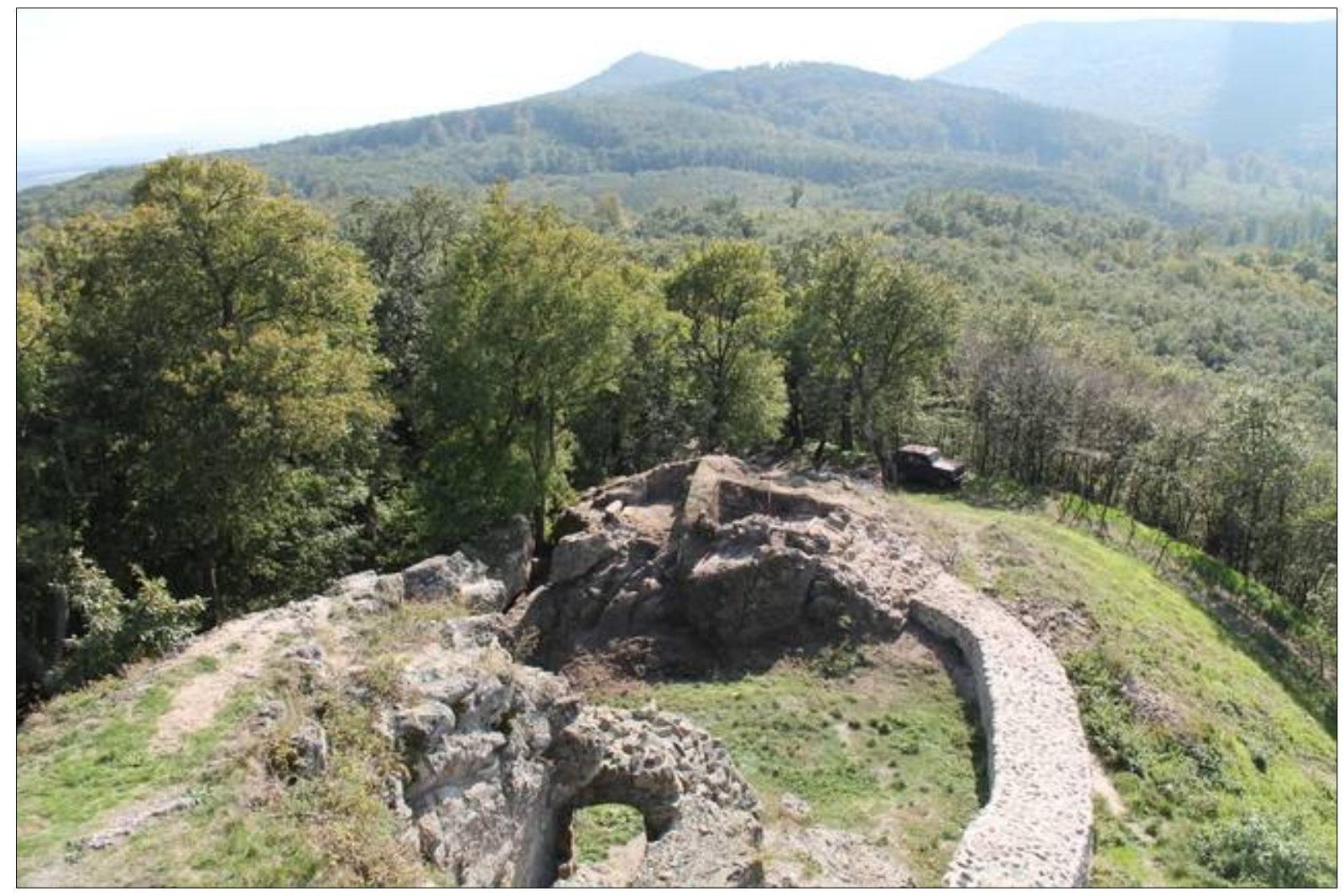

Fig. 44. The view of the excavation from the upper castle (Drégely).

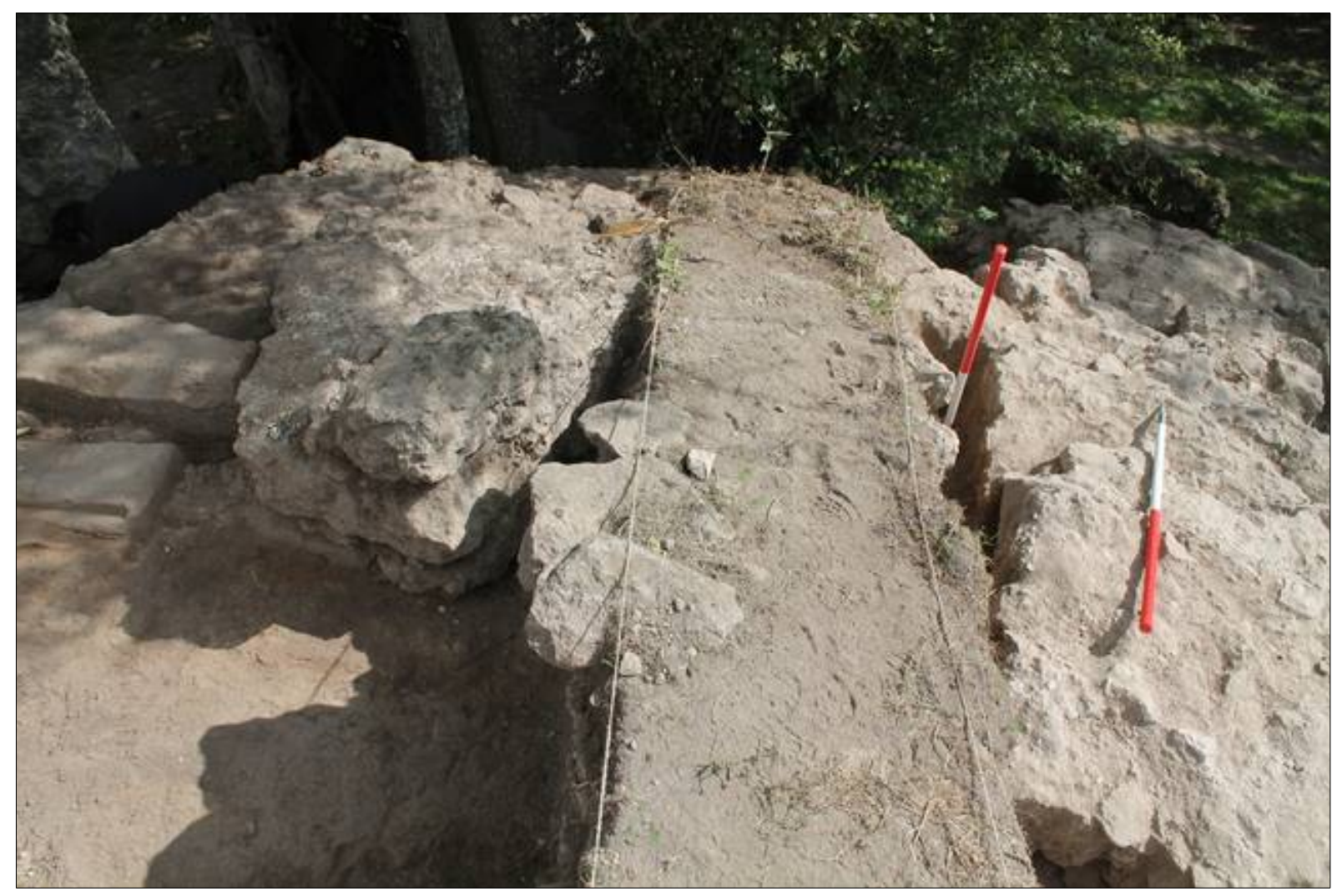

Fig. 45. The view of the south-eastern embrasure (Drégely). 


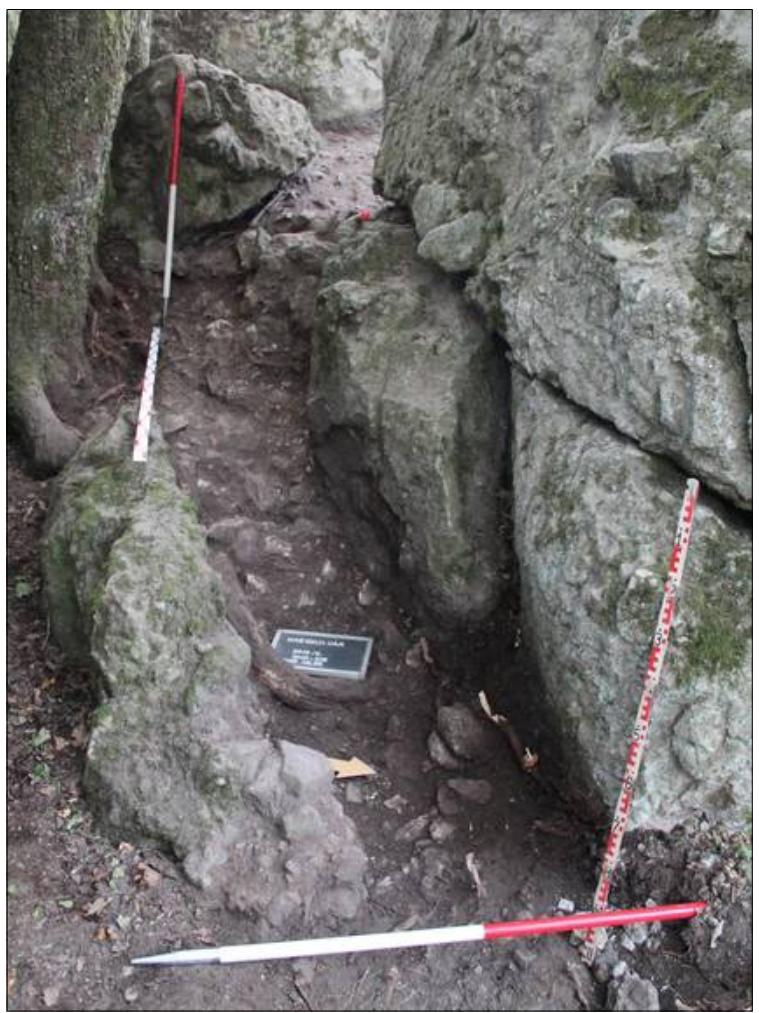

Fig. 46. The smaller entrance of the artillery tower cut into the rock (Drégely).

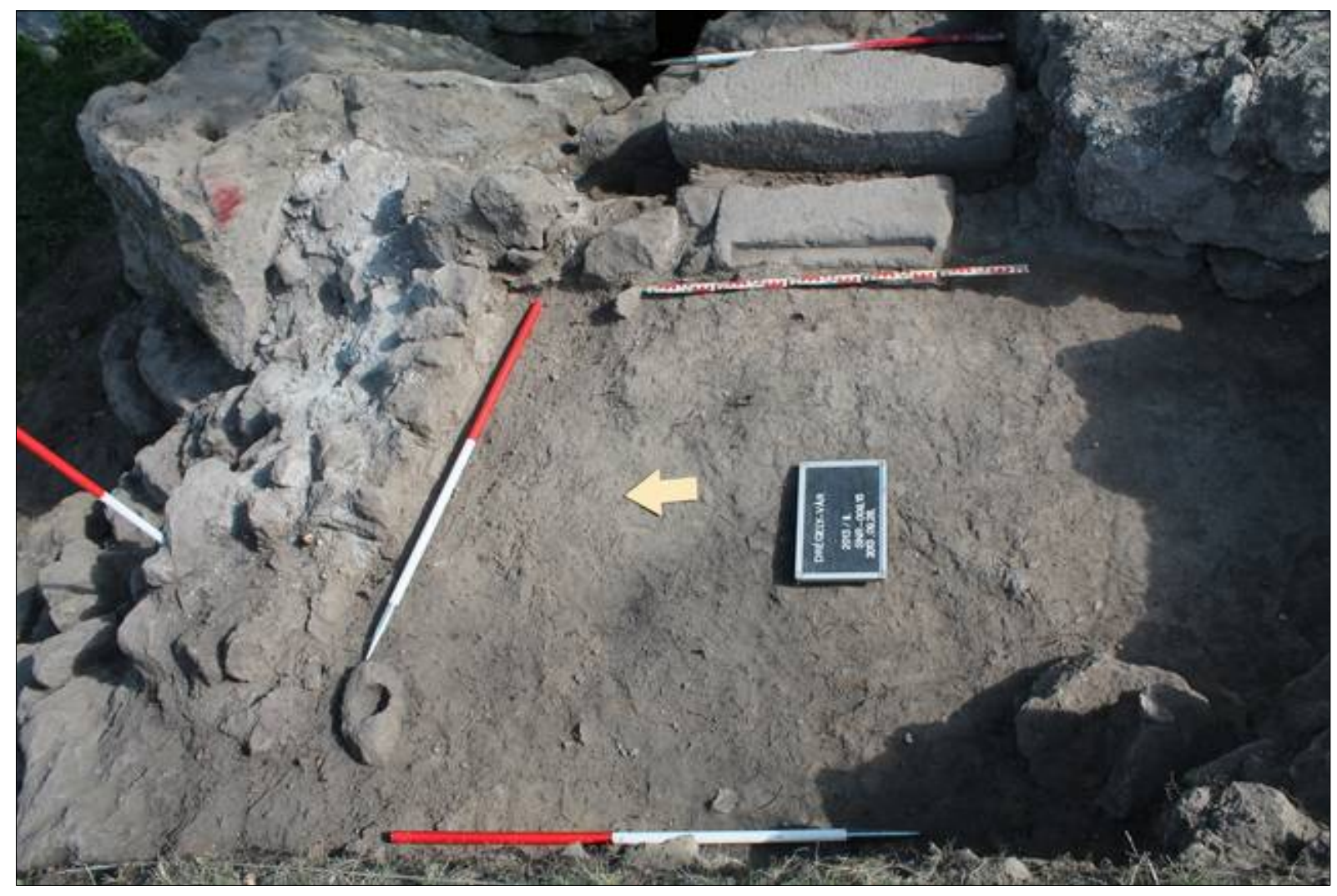

Fig. 47. The north-eastern corner of the tower with the smaller entrance and the carved "shaft" of the northern gate (Drégely). 


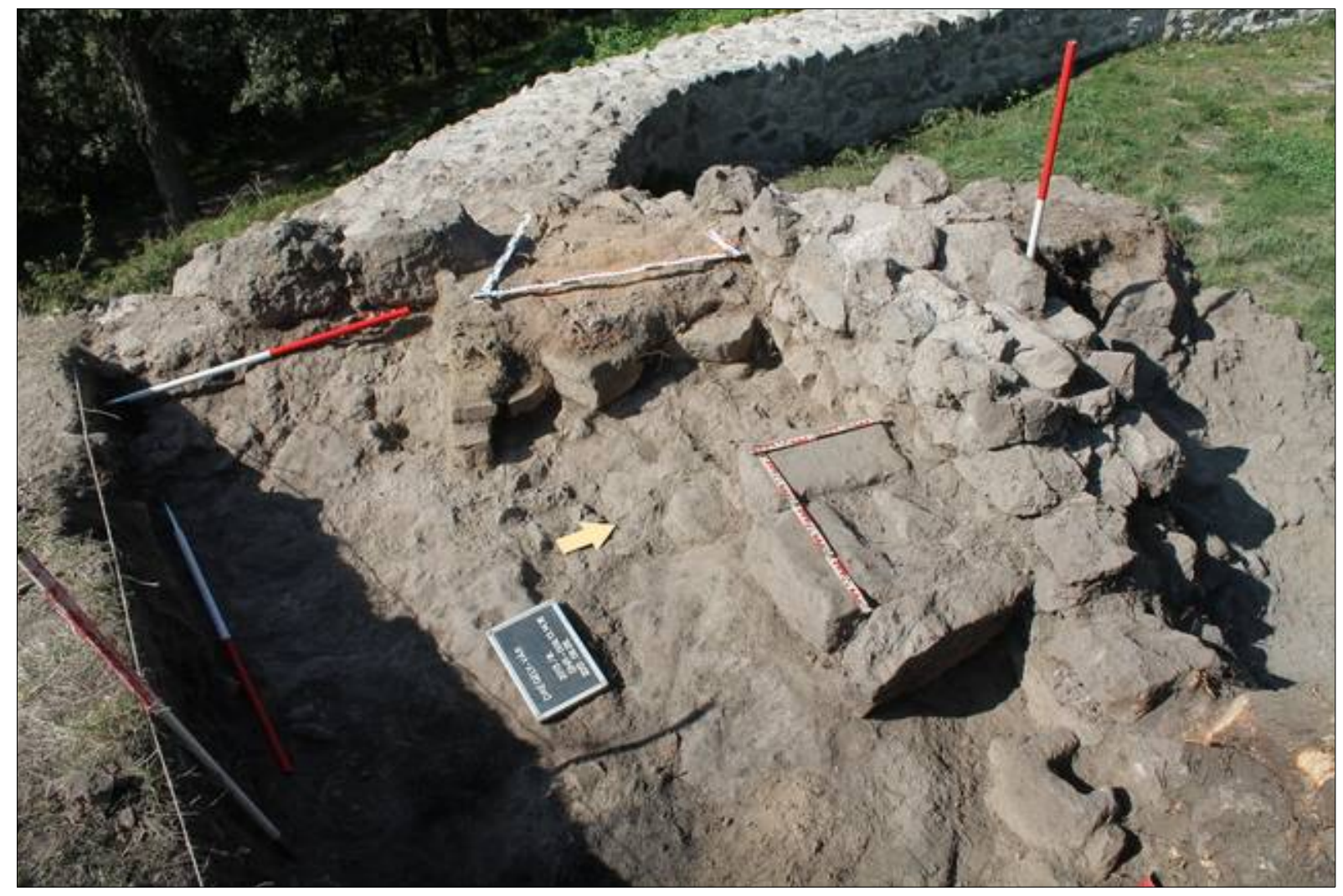

Fig. 48. The north-western corner of the tower with the site of the stove and crane foundation (Drégely).

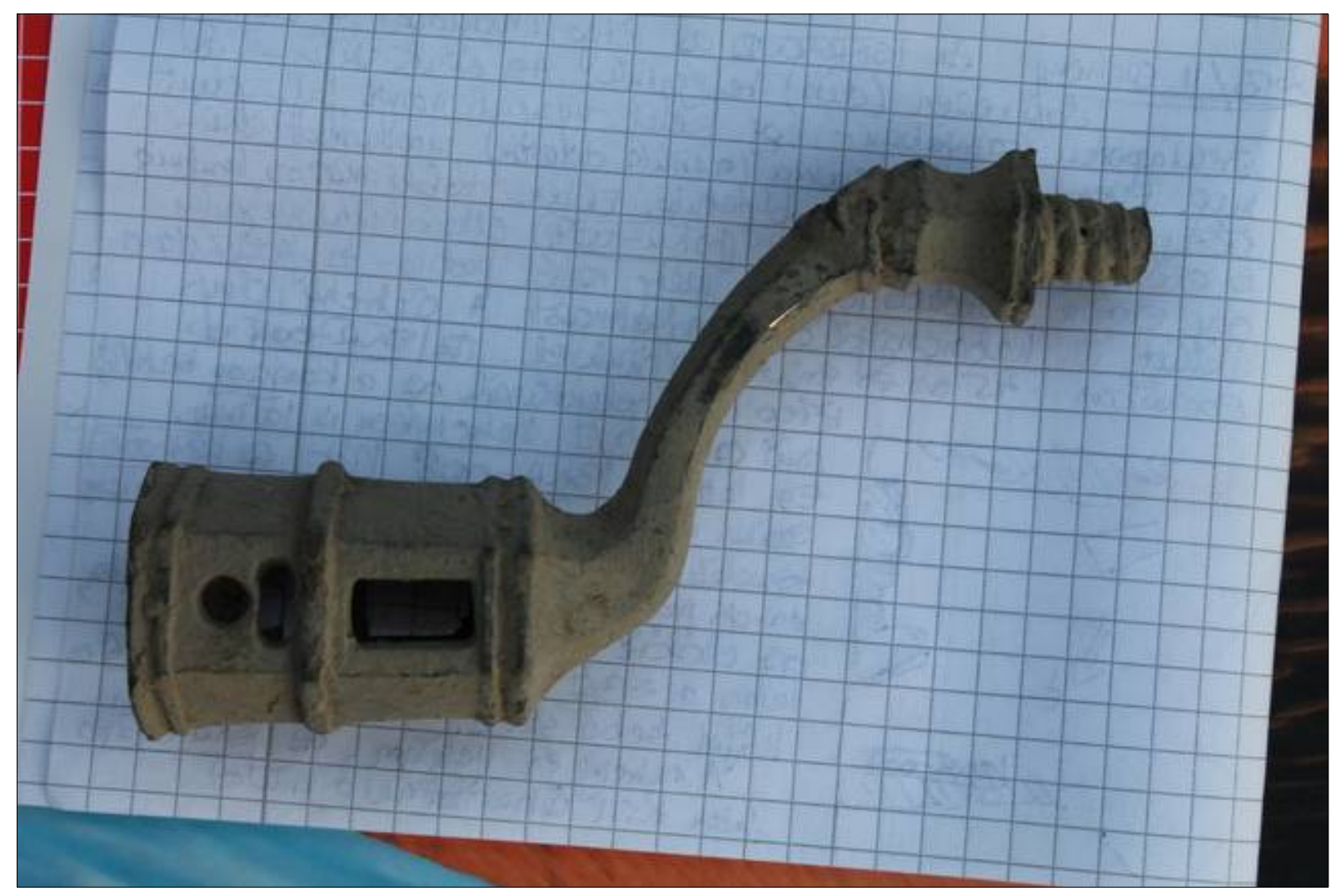

Fig. 49. 15th century candlestick from the debris (Drégely). 